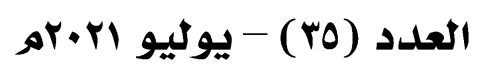

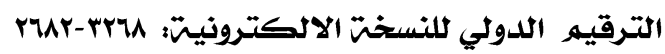

مجلتّ كاليتش التربيت - جامعت بورسعيد

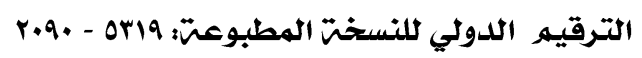

\title{
Korthagen's Onion Model and its Effectiveness in Developing Reflective Thinking Skills and Attitudes Toward the Profession among EFL Student-Educators
}

\author{
د. هاجد همصددين \\ مدرس اللغة الإنجليزية لغير المتخصصين بكلية \\ التربية ببورسعيد
}

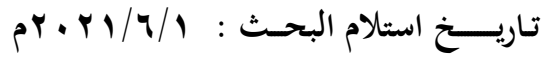

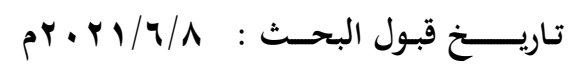

البريد الالكتروني للباحث : maged.mohamaden@edu.psu.edu.eg

DOI: JFTP-2106-1142

Faculty of Education Journal - Port Said University

Printed ISSN : 2090-5319

VOI. (35) - july 2021

On Line ISSN : 2682-3268

website : https://jftp.journals.ekb.eg/ 


\section{ABS'TRAC'T}

Korthagen's Onion model is one of the influential novelties of the Core Reflection approach, including exterior layers of reflection expanding from the surface to the interior ones. The aim of this study was to investigate the effectiveness of a proposed training program based on the Onion model in developing reflective thinking skills and attitudes towards the profession among EFL student-educators. This experimental study was conducted with 59 EFL student-educators involved in the program of teaching practice at Port Said Faculty of education. The data were collected using two scales designed to measure participants reflective thinking skills and attitudes towards the profession. The proposed training program based on the Onion model included (20) sessions and lasted for (10) weeks. Data of the pre-, post- and follow-up applications of the scales were collected and statistically analyzed. The results of the analyses revealed that the proposed training program based on the Onion Model helped to develop reflective thinking skills and positive attitudes towards the EFL profession among EFL Student-Educators. Implications, suggestions for further research, and recommendations for curricula and policy makers of teacher education programs are included.

KEYWORISS: EFL Student-Educators, Reflective Thinking, the Onion Model, Attitude, Profession 
Korthagen's Onion Model and its Effectiveness in Developing Reflective Thinking Skills and Attitudes Toward the Profession among EFL Student-Educators

د. ماجد محمدين

نموذج البصلة لكورتهاجين وأثره في تنمية مهارات التفكير التأملي والاتجاه نحو المهنة لاي

الطلاب المعلمين للغة الإنجليزية

\section{|ll|}

يعد نموذج البصلة لمبتكره الباحث كورتهاجين واحداً من النماذج المشهود لها في تدريب المعلمين

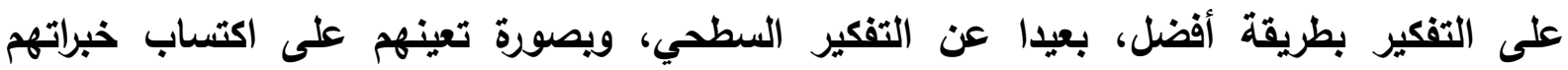

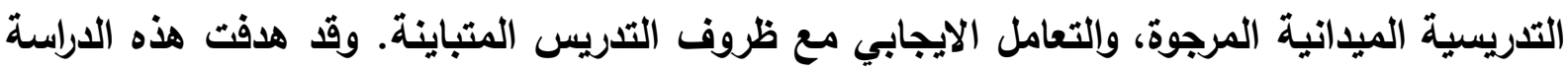

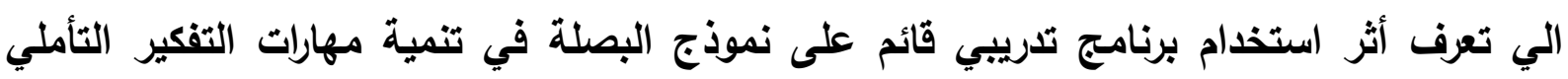

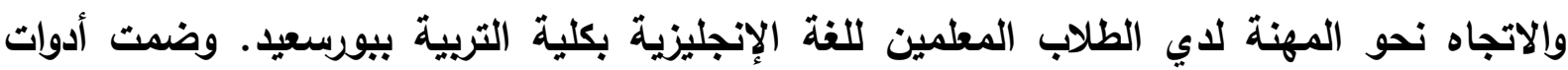

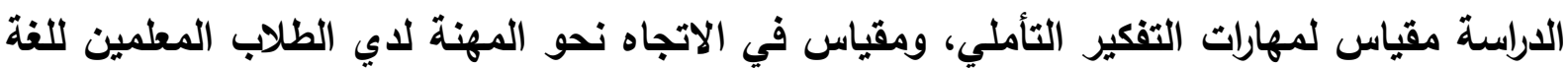

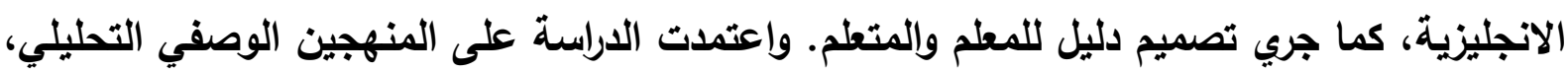
والتجريبي في بناء وتطبيق البرنامج التريبي المقترح. وضمت عينة الدراسة الطلاب المعلمين للغة الإنجليزية بالمستوي الرابع بقسم اللفة الإنجليزية، من المنخرطين في برنامج التربية العملية بالفصل

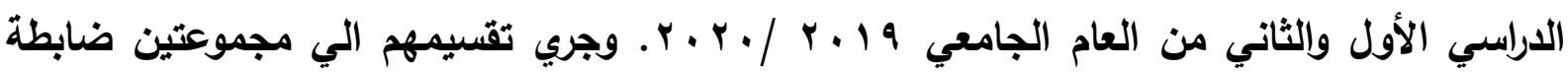

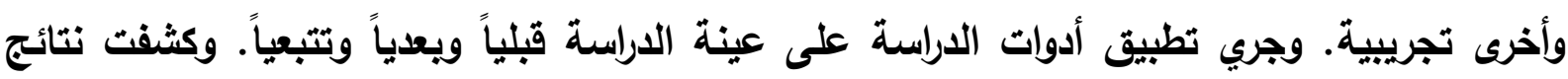

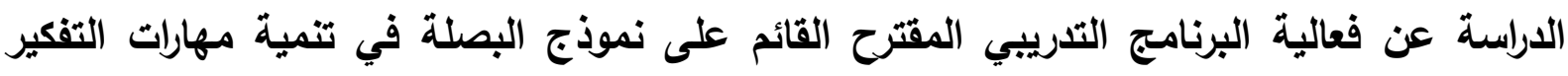

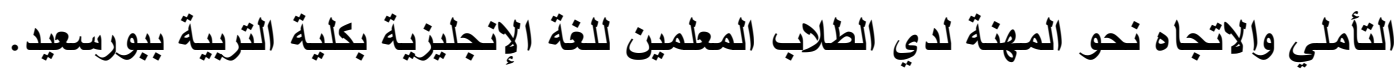

الكلمات الفتتامية: نموذج البصلة، مهالات التفكير التأملي، الاتجاه نحو المهنة، الطلاب المعلين للغة الإنجليزية. 


\section{Introduction:}

The development of qualified EFL student-educators occupies a dominant place in the field of teacher education. In this regard, there is a general consensus among EFL educators that EFL student-educators meet hard conditions that pose a multitude of challenges in their teaching practice (e.g., Körkkö, et al, 2016; Johnson, 2009). A possible challenge is that they have to keep their knowledge of the language skills updated in a context providing few chances to use them appropriately. Additionally, they have to continually integrate many modern teaching methods and technologies to improve their teaching of EFL. What is more challenging is that their teaching action and reactions are affected by their personal characteristics, beliefs, morals and attitudes proved to be influential to the strategies they use for coping with the aforementioned challenges (Farrell, 2004). To handle such continued challenges successfully, EFL student-educators need to develop efficient skills and positive attitudes toward their potential profession (Zwart et al., 2015; Black, 2015).

Amid these internal and external challenges, student-educators, in a conscious and systematic manner, regularly reflect on their teaching experiences to see mistakes and improve on them, create new goals, and foster linkages between theoretical and practical aspects of their language instruction (Hussein, 2018; Fatemipour, et al., 2014; Javadi \& Khatib, 2014). This process of self-observation and evaluation is known as reflection, a key concept understood as a continual systematic way of thinking. Reflection helps EFL student-educators analyze their teaching context, their thoughts and actions as a means of future professional development. This is evidenced by numerous researchers. For instance, Rodgers (2002) emphasized that reflection is a key element in an EFL teacher's professional development as it helps them face and generate possible solutions for the problems and questions posed in the teaching context, as well as to sort out and live with working hard conditions. Beauchamp (2015) also asserted that reflection is a key factor in shaping and directing teacher's work, sustaining commitment and retention, and in the future plans and actions. Furthermore, a number of theoretical and empirical studies mentioned varied benefits of reflection, including higher self-confidence (Finkel \& Fletcher, 2002), effective team teaching partnership (Perry \& Stewart, 2005), improved performance (Tillema, 2006), keeping portfolios (Mansvelder-Longayroux, et al., 2007), more effective self-evaluation (Genc, 2010; Jung, 2012), and stronger reasoning (Abednia, et al., 2013).

More specifically, reflective thinking, an indispensable component of reflection, is a concept of paramount importance to help EFL teachers observe and evaluate their teaching, develop strategies for effective 
instruction. This concept has recently received a noticeable attention in the field of EFL teaching. For example, the study of Choy \& Oo (2012) discussed reflective thinking based on four characteristics: (a) reflection as retrospective analysis: reflection is precursor for incorporating prior experiences to influence the current teaching practices of teachers. This allows for teacher's self-assess, (b) reflection as problem solving: reflection is precursor for analyzing and articulating problems before taking constructive actions rather than implementing a quick fix, c) critical reflection of self: reflection is precursor for analyzing, reconsidering and questioning personal experiences within a broad context of issues such as the use of technology as well as the ethical aspects, and d) reflection on selfbeliefs and self-efficacy: teacher's self-feelings and beliefs towards himself and others are significant to the way adopted in teaching.

In this regard, both theoretical and empirical studies (e.g., Burbank, et al., 2012; Choy \& Oo, 2012; Bell et al., 2011; Campoy, 2010; Pagano \& Roselle, 2009; Sezer, 2008; Rudd, 2007) highlighted the significant role that reflective thinking skills play in urging EFL teachers to reflect on the available options, draw conclusions, and consequently develop a positive attitude towards their professional development. For instance, Sezer (2008) noted that EFL teachers who think reflectively become aware of and control their teaching and able to bridge the gap between theoretical and practical aspects of their instruction. Moreover, Rudd (2007) proposed reflective thinking, during problem solving situations, is significant to help the thinker step back, analyze, evaluate and think of the best strategies to achieve the intended goals.

The core reflection is a relatively recent approach in the field of teacher education programs that considers teachers' personal qualities and ideals as a starting point for reinforcing teacher reflection, in both the short and the long term, and in-depth professional development (Kizilcik \& Daloglu, 2018; Korthagen \& Vasalos, 2005). As held in previous related literature (e.g., Korthagen \& Nuijten, 2017; Impedovo \& Malik, 2016; Conway \& Clark, 2003), the goals of the core reflection approach are: "(1) building on personal strengths and ideals, (2) to face personal inner restriction and obstacles that hinder and prevent the actualization of inner potentials, and (3) to help deal with obstacles and restriction in an independent way.

The onion model is one of the influential novelties of the Core Reflection approach, proposed by Korthagen in 2004. It is an instructional approach designed to develop reflective thinking. It is characterized by its easiness to understand and use, clear practical application, and the major changes it develops in EFL teachers' practices (Ashrafi, et al., 2020; Nur \& Cephe, 2017). From its perspective, teacher's inner obstacles of reflection go through six layers, including: (1) The environment: a layer concerned with 


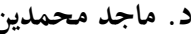

everything outside a teacher own self; (2) Behavior: a layer concerned with what and how the teacher does and copes with the environment challenges; (3) Competencies: a layer concerned with the teacher's own capabilities; (4) Beliefs: a layer concerned with the teacher's own beliefs about the instructional situation; (5) Identity: a layer concerned with how teachers see themselves and their professional roles; and (6) Mission: a layer concerned with teachers' own ideals that gives meaning and significance to their work or lives.

A growing body of research has been investigating the significance of the onion model in developing teacher's reflection. For instance, AttemaNoordewier, et al., (2013) concluded that the onion model provides many options to the EFL teacher and students, and for the school culture as a whole. At the teacher level, increased feelings of autonomy, increased selfefficacy, increased coaching skills, renewed insights of the learning process, and higher awareness of core qualities among EFL teachers and students were found. Additionally, an increase in the students' communication skills and positive attitudes were found. Güngör (2017) also used the onion model to investigate EFL teachers' active involvement in the processes of planning, teaching and evaluation. It was concluded that the onion model has a key role in harmonizing macro-policies of EFL teaching and its practices in the micro-levels.

Few studies in the Arab world have investigated the effect of using the onion model to develop EFL student-educators reflective thinking. On the other hand, the relationship between reflective thinking and EFL studenteducators' attitudes towards the profession is not clear. So, there is a need for a study intended to narrow these gaps. This study explored the possible effectiveness of a proposed training program based on the Onion model in developing reflective thinking skills and attitude towards the profession among EFL Student-educators.

\subsection{Context of the Problem}

Development of modes of thinking (e.g., critical, analytical, creative and so forth) is a very important topic in the field of teacher education. Reflective thinking is one of such modes necessary to help EFL studenteducators examine, evaluate and react in their teaching, seen as a source for effective professional development. A glance at the EFL recently published research reveals that developing reflective thinking skills is of utmost importance for EFL teaching (e.g., Nosratinia, M., \& Zaker, 2017; Soodmand \& Farahani, 2015; Gurol, 2011; Jansen \& Spitzer, 2009; Hua, 2007).

Despite such assumed importance of reflective thinking skills, the researcher' observations and experience as supervisor of EFL studenteducators as well as a director of the Languages \& Translation Unit of the 
Public Service Centre at Port Said Faculty of Education supported that most of the EFL student-educators do not reflect deeply on their teaching practices. Often confronted with a number of signs of their avoidance of reflection. Critical situations are everywhere in the context of teaching practice; however, the researcher has found EFL student-educators unable to evaluate their teaching, to adopt a systematic approach to teaching, unable to determine learning styles and strategies do their learners favor, unable to determine their aspects of weakness and improve on them, and unable to collaborate effectively with other colleagues. Gradually, most of them has developed a low sense of self-efficacy and a decrease in their job satisfaction.

The researcher has conducted semi-structured interviews with a sample of 13 participants of EFL student-educators to explore their perceptions of the current process of teaching practice. They indicated that they work in varied situations, delivering English with different kinds of contents to beginning learners, intermediate students and advanced ones. They mentioned many problems related to evaluating their teaching. They indicated that their supervisors rarely give them practical help with their problems. They reported they joined a number of workshops in the faculty designed to improve their language teaching skills which found having only short-term effects and rarely involving theme in an ongoing process of examining their teaching, leading up to low attitudes towards the profession.

Based upon these interviews, it was evident that EFL student-educators need a training program designed to meet their specific needs, enhance their reflection and engagement, and will later help them develop a better attitude towards the profession. Findings from previous related studies (e.g., Ashrafi, et al., 2020; Güngör, 2017; Korthagen, 2017; AttemaNoordewier, et al., 2013;) present positive results regarding the role that the onion model, proposed by Korthagen in 2004, can play in the development of reflective thinking skills and attitudes towards the profession among EFL teachers, and is thus worth attention. However, little empirical evidence in the Arab world indicating that constructive role. Inspired by this scarcity of research in the Arab area, this study was to examine the effectiveness of a proposed training program based on the Onion model in developing reflective thinking skills and attitude towards the profession among EFL student-educators.

\section{1-3 Statement of the Research Problem}

EFL student-educators at Port Said Faculty of Education suffer from weaknesses in their reflective thinking skills, represented in their inability to observe, evaluate and control their teaching of EFL as well as to develop strategies for effective teaching of EFL, causing to low negative attitudes 


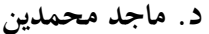

towards the EFL profession. These aspects of weaknesses may be attributed to their inappropriate training on reflective thinking skills. Using a proposed program based upon the Onion model and investigating its effect on developing their reflective thinking skills and attitude towards the profession, is suggested in this research.

\subsection{Research Questions}

To address the research problem, the main research question of this study is: "What is the effectiveness of a proposed training program based upon the Onion model in developing reflective thinking skills and attitude towards the profession among EFL student-educators at Port Said Faculty of Education?"

In this regard, the following questions are derived:

1. What is the onion model?

2. What are the components of the proposed training program based upon the Onion model?

3. What is the effect of the proposed training program on developing reflective thinking skills among EFL student-educators at Port Said Faculty of Education?

4. What is the effect of the proposed training program on developing attitudes towards the profession among EFL student-educators at Port Said Faculty of Education?"

\section{1-5 Aims}

To investigate the effectiveness of a proposed training program based upon the Onion model in the development of reflective thinking skills and attitudes towards the profession of EFL student-educators at Port Said Faculty of Education, was the main goal of this study is. To achieve this ultimate aim, this study is endeavored to fulfil the following objectives:

1. To highlight what the Onion model and reflective thinking skills are, and how EFL student-educators at Port Said Faculty of Education can successfully acquire them as a way to develop their attitudes towards the EFL profession.

2. To consider and adopt a new methodology for preparing competent EFL student-educators in a way that could contribute for the development of teaching practice.

3. To provide a concrete experiment for empirical research into the validation of the Onion model in the Arab area in a way that could maximize opportunities to forge stronger connections between theory and practice.

\section{1-6 Significance}

The outcomes of this study can contribute to: 
1- Provide supervisors of EFL teaching / teaching practice a new methodology for exploring EFL teaching process through a practical model that can serve as a basis for professional development.

2- Help EFL teachers / student-educators make visible and positive change in their language teaching in the EFL classroom through planned activities.

3- Instill a desire among EFL university curricula developers / policy makers to develop the current program of teaching practice as the proposed training program gives a richer conceptualization of EFL teaching and learning processes at the university level.

4- To provide language researchers and scholars considerable implications for teaching practice and better understanding of language competence and the importance of self-reflection for EFL educators.

\section{1-7 Procedural Definitions of Terms:}

1. Reflective Thinking Skills: a set of mental abilities required to help EFL student-educators at Port Said Faculty of Education analyze, reflect on, and modify their teaching in the EFL classroom.

2. Attitude towards the Profession: a set of acquired, not natural, favorable or unfavorable, behaviors demonstrated by EFL student-educators at Port Said Faculty of Education relating to remaining committed to their EFL profession.

3. The Onion Model: a model proposed by Korthagen (2004) to enhance teachers' reflection on daily instructional situations they are confronted with.

\section{Theoretical Framework}

This part reviews relevant previous literature on the Onion model, reflection, reflective thinking skills and tools utilized for promoting teacher reflection. The significance of the EFL student-educators' attitudes towards the profession have also been discussed.

\subsection{Reflection and Reflective Thinking skills}

Teaching, in general, is a complex, dynamic, interactive profession. Upon involving in teaching, it is essential for EFL teachers to constantly engage in a continuous thinking process to gauge the consequences and outcomes of their actions, to cope skillfully with varied challenges relating to delivering information to students, and to analyze interactions with students. This process of self-observation and evaluation can be described as reflection, which is a relatively old concept, first proposed by John Dewey. Varied definitions have been provided for this concept. For example, reflection, as held by Dewey (1933: 9), is an active, persistent, and careful consideration 
of a belief that supports a form of knowledge, leading to further conclusions. In addition, as held by Daudelin (1997: 39), reflection is to step back from a personal experience to analyze, evaluate and ponder, in a conscious manner, its meaning to the self through the development of inferences.

In prior literature, reflection is regarded to be a systematic, purposeful, developmental meaning-making process. Such a process is of utmost importance for teachers, resulting in meaningful future practices that can help them remain committed to their profession. Overall, reflection, in related literature, remains a key component of the teaching profession. For instance, it helps teachers refine and develop useful information, thoughts and knowledge about their profession (Loyghran, 2002). Additionally, it provides teachers with the opportunity to transfer their theoretical or pedagogical knowledge into their teaching experience in the classroom (Erginel-ganal, 2006). Likewise, it increases the capacity of teachers to make better use of personal judgements in the classroom (Pollard, et al., 2008). Further, the findings of Farrell (2011) indicated that reflection help teachers develop a deeper understanding of instructional processes as well as student progress. In a more recent study, reflection seems to provide teachers with necessary tools to self-assess their beliefs, thoughts and knowledge (Cirocki \& Widodo, 2019).

In this regard, reflective thinking, an indispensable component of reflection, has received a growing concern in both theoretical and empirical past studies. Most researchers argued that reflective thinking is used by teachers to interpret and comprehend the teaching experience, establish expectations, and utilize instructional and management routines in favor of the development of the teaching process (e.g., Lee, 2005; Muir and Beswick, 2007; Sezer, 2008; Zeichner and Liston, 2013). Originally, Dewey (1933: 20) asserted that those who make use of reflective thinking can predict and potentially avoid unwanted consequences and gain "intellectual mastery". Furthermore, in a recent study, Sezer (2008) concluded that those who think reflectively control their learning and can easily access what they know as well as what they need to know on one hand, and how to bridge that gap between both on the other hand. Added to this, Zeichner and Liston (2013) believe that the teachers who are reflective thinkers are only those whose teaching activities involve a wide range of examining, planning, and raising questions regarding the ideas, thoughts, values and assumptions of what they teach.

Prior literature has witnessed a proliferation of studies dedicated to examining reflective thinking skills. For instance, Dymoke and Harrison (2008) put more attention on observation, communication, judgment, decision making, and team working as the main reflective thinking skills. 
Observation is necessary to notice, mark and record teachers' feelings, thoughts and behaviors for further use. Communication with mentors through formal professional portfolio, journals, or diaries is indispensable to avoid misunderstanding, failure and frustration. Realistic judgment, the very basis of reflective thinking, is important to analyze all details and components involved in the teaching situations. Decision making is an influential skill to help teachers achieve the instructional goals within the given time and handle work situations. Team working is considerable to solve problems and come up with creative solutions of doing daily things.

In the same context, the findings of Choy \& Oo (2012) indicated the significance of the following reflective thinking skills to ensure that teachers are practicing their daily jobs accurately and properly: the ability to selfassess, awareness of how one learns, developing continuous selfimprovement, the ability to reflect on beliefs about the self and self-efficacy. The ability to self-assess is a basic skill to incorporate prior experiences in a way or another to positively influence current teaching practices. Awareness of how one learns is a required skill to consider, trace, analyze and compare problems before starting to take action. Added to this, developing continuous self-improvement is requisite to help teachers perceive current realities of work and its likely futures and how to provide alternative ways of practicing teaching. Further, the ability to reflect on beliefs about the self and self-efficacy is a crucial skill because teachers' beliefs towards themselves, values and world views affect the strategies they use to achieve their intended goals.

In this respect, several tools have been suggested in previous literature to foster reflective thinking skills, categorized as conventional tools (e.g., journals, portfolios,) and technology-oriented tools (e.g., video recordings, electronic dialogue journals, chats or internet relay chats, blogs, online discussions) (e.g., Zulfikar \& Mujiburrahman, 2018 Uzum, et al, 2014; Jones and Ryan, 2014; Collin \& Karsenti, 2012; Welsch \& Devlin, 2007; Good \&Whang, 2002). As held by Good \&Whang (2002), journals, that include clear and stimulating reflectivity prompts help preservice teachers reflect upon their own growth as reflective practitioners, increase their understanding of the intricacy of EFL teaching and learning, and incorporate theoretical and practical issues. Equally important is to use video recordings. The findings of Halter (2006), Romano \& Schwartz (2005) and Welsch \& Devlin (2007) agreed that video recordings encourage preservice teachers to reflect on personal teaching practices and think of the complexity of classroom teaching in real situations. In addition, they provide useful information for different issues go unnoticed in the context of the teaching process such as students' responses to instruction, the favorable feedback and the factors that influenced their decision making. 
Such information could help the preservice teacher analyze, reflect on, and modify their teaching practices.

Moreover, blogs and online discussions have been suggested in previous literature for promoting reflective thinking skills (e.g., Tang, 2013; Killeavy \& Moloney, 2010; Sun, 2010; Yang, 2009; Romano \& Schwartz, 2005). Killeavy \& Moloney (2010) indicated blogs and online discussions that involve preservice and Inservice teachers in the reflective process help participants combine their internal dialogue, thoughts, opinions, views, and reflections. However, their use. Romano \& Schwartz (2005) suggested the following four components to make online discussions more meaningful and reflective: (1) participation on a regular basis; (2) involving mentor teachers as a part of the discussion; (3) offering a variety of reflective discussion topics; and (4) including out-of-state teachers as participants in the discussion to get a different perspective on the topics discussed.

In brief, reflection is a regular activity practiced by EFL studenteducators. It enables them to deal with complex and pressing educational issues. An EFL student educator constantly engages in a reflection process as a basic way to evaluate his/her own teaching methods and strategies, seek alternatives, and assess available procedures to achieve the intended goals and ensure student learning. Accordingly, it is important to promote reflective thinking skills, an indispensable component of reflection, to help EFL student-educators analyze, evaluate and develop their instruction.

In this respect, such complex and pressing educational issues, if continued, may lead EFL student educators possessing negative attitudes and a loss of interest in the teaching profession. The next section gives a description of this significant problem.

\section{2 Attitudes toward the Profession}

It is acknowledged teaching practice is an integral part of the program of EFL teacher preparation in faculties of education to get EFL studenteducators exposed to actual and real teaching. The impact of this actual practice on their attitudes towards their profession is a relatively researched topic in related literature (e.g., Salehi, et al., 2015; Al Harthy, et al., 2013; Hettiarachchi, 2013; Cristina-Corina \& Valerica, 2012; Hürsen, 2012). There is consensus in the aforementioned studies on the fact that EFL pre-service teachers attitudes towards the teaching profession largely influence their teaching performance, their implementation of effective methods, their use of significant techniques to help students learn the foreign language properly and accurately.

In general, both theoretical and empirical related studies have investigated student-educators' attitudes towards their profession in terms of their relationships with other factors, mainly categorized as schooloriented factors (e.g., school environment, management, school size) and 
د. داجد محمدين

personality-oriented factors (e.g., age, gender, motivation, experience).

For instance, the school environment has been reported as a main influencing factor. Hettiarachchi (2013) revealed that EFL teachers' attitudes toward the profession are positively affected by the following aspects closely related to the school environment: student performance and success, being with motivated students, recognition and appreciation by students, and students' positive attitude towards English. Conversely, their attitudes towards the profession are negatively affected by limited facilities, overcrowded classes, school-based assessments, colleagues who don't work, inappropriate textbooks, teaching methodology, frequent changes of syllabus and textbooks, and poor knowledge in teaching methods. In a similar vein, Hürsen (2012) indicated that age, gender, and experience are the main influencing factors on teachers' attitude toward teaching EFL. Namely, female teachers and less experienced teachers hold less favorable attitudes toward teaching EFL. In contrast, male teachers and more experienced teachers hold favorable positive attitudes toward teaching EFL.

Further, Smadi \& Al-Ghazo (2013), after delivering a questionnaire to 20 female EFL teachers, declared that instruction competences have the remarkable role in shaping teachers' attitude toward teaching EFL. Moreover, Sireesha \& Reddy (2015), after delivering a questionnaire to 240 participants working as language teachers at high schools, showed that factors of management and qualification are the main influencing factors contributing to EFL teachers' greater excitement in language instruction, and causing them exert more effort. Considering the variables of the current study, reflection has been reported as one the influencing factors on student-educators' attitudes towards their profession. Pacheco (2005) indicated that negative reflection has overwhelming effects on teachers' sense of efficacy, learners' achievement, and teachers' performance in the EFL classroom.

To summarize briefly, given the importance of EFL student-educators' attitudes toward the teaching profession, the current study aims to shed light on them as a considerable determinant of their future EFL teaching' success. For the purposes of the current study, EFL student-educators ' attitudes toward their profession have been investigated in the current study in terms of their interconnection to reflection. Looking at the big picture, several researchers have developed varied models, strategies and theoretical frameworks in order to develop, analyze and investigate reflective thinking skills of teachers and develop their attitudes. The next section gives a detailed description of the Onion model, an influential model in this area. 
د. ماجد محمدين

\subsection{The Onion Model}

EFL student-educators, by nature, are expected to be fair, well organized, dedicated to the profession, use easy and effective methodologies, equipped with the skills and experiences required to teach the foreign language successfully. This requires them to regularly reflect on their experience and rethink of the best way to evaluate and develop their teaching practices (Vermunt \& Endedijk, 2010).

In this context, a new approach of a growing interest called the Core Reflection was developed (Korthagen, 2014, 2016, 2017; Korthagen \& Vasalos, 2005, 2010). This approach focuses on teachers' core qualities and ideals (such as empathy, compassion, flexibility, courage, creativity, sensitivity, spontaneity kindness and fairness) as the foundation of teachers' guided reflection. A central issue in this approach is to integrate the personal thoughts, feelings, needs, desires and ideals of teachers to the professional aspects in teaching, as a way to enhance teachers' professional growth. There are seven major principles of the Core Reflection approach, taken from the findings of Meijer et al., (2009), to ensure the use of teacher's best capacities in the teaching process.

1. to promote awareness of the situation and ideals and core qualities related.

2. to identify the internal obstacles that prevent these ideals and core qualities to act.

3. to promote awareness of the cognitive, emotional and motivational aspects embedded in ideals, core qualities, and obstacles.

4. to promote a full state of awareness of the nature of the internal obstacles.

5. to develop one's trust in the process that takes place from within the person.

6. to foster inner potentials and capabilities included in the situation under reflection.

7. to promote autonomy.

The onion model, proposed in 2004 by Korthagen who is an influential contributor to the Core Reflection approach, is one of the prominent models used to enhance teachers' reflection on daily instructional situations they are confronted with, their behaviors, their skills and their thoughts and beliefs in such situations. This model takes its name as the onion model because of its shape. As shown in figure (2.1), the onion model includes a number of circles, looking just like an onion cut in half from the middle; symbolizing various layers or levels that can influence the teacher's reflection. These influential layers are: 
د.

1. The environment. It relates to everything the teacher encounters outside of himself/ herself, involving the school context, the classroom setting, the students, the subject matter, and the school culture.

2. Behavior. It signifies everything the teacher does to cope with the environment challenges.

3. Competencies. It involves everything the teacher is skillful, proficient and competent at doing.

4. Beliefs. It includes the teacher's assumptions about the situation being dealt with.

5. Identity. It includes the teachers' assumptions about themselves, their professional roles, self-concepts and self-efficacy.

6. Mission. It includes the teacher's inspiring ideals that provide meaning and significance to the teaching profession.

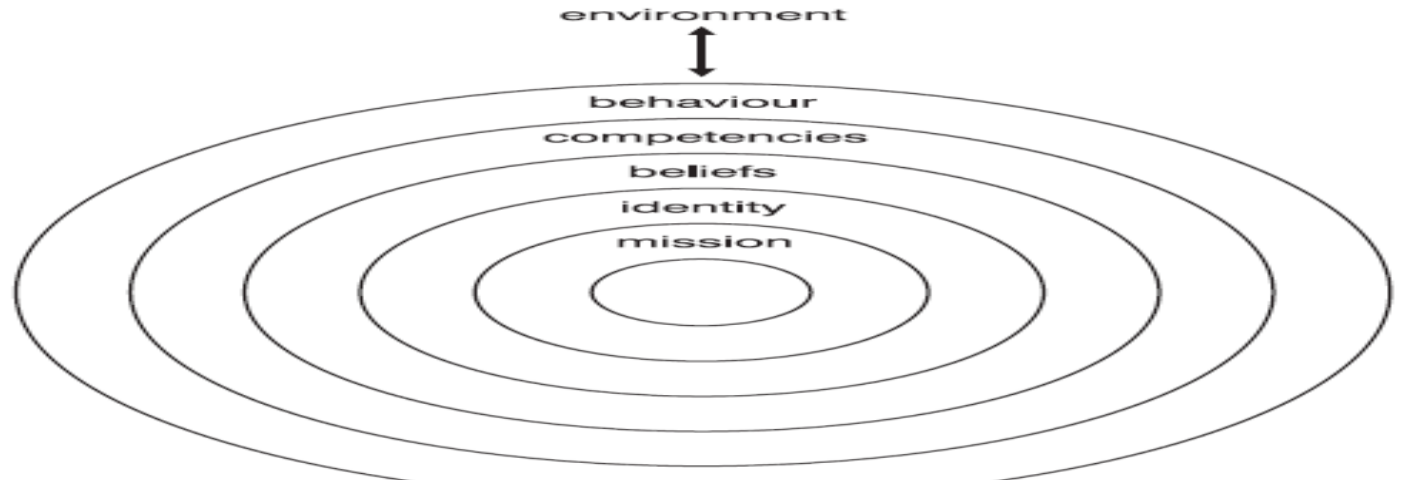

Figure 2.1. The onion model describing different levels of teacher's reflection.

(Source: Nur \& Cephe, 2017)

The main idea behind designing the onion model is to make optimum use of the inner levels as well as the outer levels to positively enhance the effects of the teacher's reflection. A symbiotic relationship seems to be found between these six layers of reflection, as the outer layers can influence the inner ones, and vice versa. For example, from the outside to the inside, the outsider environment may have an impact on the teacher's behavior (ex: a large classroom of students leads the teacher to produce reactions very different from that of a small classroom). On the other hand, an opposite effect exists as well from the inside to the outside, as the teacher's behavior can influence the environment (a teacher can positively affect a child through using group work).

Additionally, the heart of the onion model contains significant core qualities for teachers that ensure that teachers are well prepared to reflect on their personal experiences, values and beliefs in order to find a rapid solution for problems at hand and produce a very motivating teaching activity, including enthusiasm, curiosity, perseverance, kindness, courage, steadfastness, creativity, sensitivity, openness, and so forth (Korthagen, 


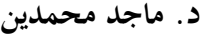

2014, 2016, 2017; Korthagen \& Vasalos, 2005, 2010). The assumption behind this is that inner obstacles are everywhere and teachers have to make use of their full potentials to deal with them.

The onion model was originated from a previous model of reflection called the ALACT model (Korthagen $e t$ al., 2001), shown in figure (2.2), which was proposed by Korthagen (1985) at Utrecht University. It was a five-phase model for reflection aiming to help teachers develop their own personal perspectives and views about teaching; including (i) Action, (ii) to look back on the action, (iii) to be aware of essential aspects, (iv) to creating alternatives of action, and (v) Trial (taking a new action). The ALACT model's success has not been proven in providing effective guidelines for developing meaning-oriented reflection.

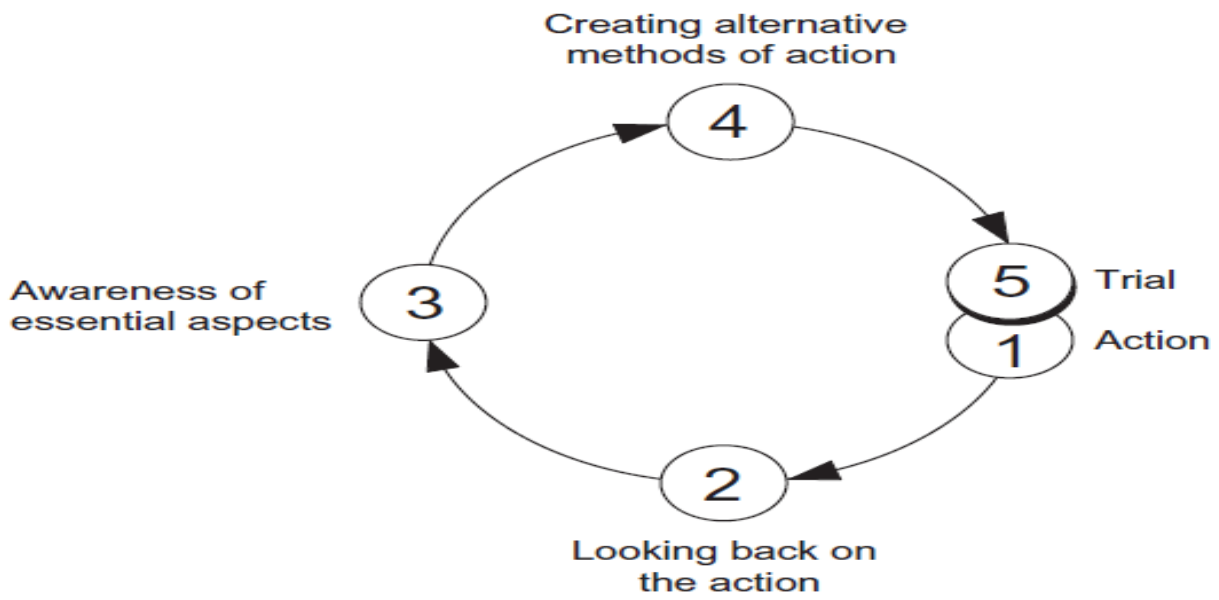

Figure 2. 2. The ALAC T model of reflection (source: Korthagen et al., 2001).

Conversely, findings from previous related studies provide positive results regarding the substantial role that the onion model can play in helping teachers reflect deeply on the consequences and outcomes of their teaching practices. According to Nur \& Cephe (2017), the Onion model is an important model to explain the systematic reflection process conducted by EFL teachers. It helps them better understand how to move from a level guided by intuition or routine to another one guided by reflection as a way to develop a healthy relationship with their teaching environments. As held by Nur \& Cephe (2017), the Onion model is an important tool for EFL teachers looking for developing their professional identity as the 6 layers included in the onion model can be actualized in English teachers, regardless of their self-inquiry and actual practices commensurate with or not. 
Furthermore, in a recent study, Ashrafi, et al. (2020) investigated the impact of the onion model on the professional development of 40 Iranian English language teachers attending three supervisory sessions of reflective practice. Their findings revealed that EFL teachers experienced a systematic developmental process of growth from the outer layers to the inner layers included in the onion model. The results also indicated that activation of core qualities, included in the onion model, is an important tool for providing EFL teachers a sense of identity and mission that positively influenced their teaching environment, behaviors, and beliefs based on their needs, responsibilities and ideals.

\section{Conclusion}

Using the Onion model of teacher's reflection is a relatively new research area in TEFL, and has recently started to receive more attention. The Onion model is a six-level model moving from the outer world towards the teachers' inner world, and vice versa. Most of the related literature on the Onion model are conceptualized or applied by Western scholars. This study intended to apply it in a local Egyptian educational context. Furthermore, previous studies regarding the use of the Onion model have merely been carried out in training programs formats with a focus on developing reflective thinking skills and attitudes toward the profession of EFL student-educators. Intended to narrow these gaps, the current study investigated the possible impact of a proposed training program based on the Onion model in developing reflective thinking skills and attitudes toward the profession among EFL student-educators.

III. Methodology

This part declares the research design, hypotheses, sampling, instruments, and procedures of data collection and analysis followed throughout the current study.

\subsection{Design}

This study has employed two methods. First and foremost, a descriptive analytical method was used to investigate reflective thinking skills and attitudes toward the profession among EFL educators, and in order to build the proposed training program. The second one was an experimental method with a two-group design. To best fit the purposes of the present study, an experimental group and a control group were adopted to investigate the impact of the independent variable (the proposed training program based on the Onion model) on its dependent variables (reflective thinking skills and attitudes toward the profession). 
د. ماجد محمدين

\subsection{Hypotheses}

This study attempted to verify the following research hypotheses:

1. There are significant statistical differences at $(\alpha \leq 0.01)$ level between the experimental group's mean scores and the control group's mean scores in the post- application of the scale on participants' reflective thinking skills in favor of the experimental group students.

2. There are significant statistical differences at $(\alpha \leq 0.01)$ level between the experimental group's mean scores and the control group's mean scores in the post- application of the scale on participants' attitudes toward the profession in favor of the experimental group students.

3. There are not significant statistical differences between the experimental group students' mean scores in the post-application and their mean scores in the follow-up application of the scale on reflective thinking skills.

4. There are not significant statistical differences between the experimental group students' mean scores in the post-application and their mean scores in the follow-up application of the scale on attitudes toward profession".

\subsection{Sampling}

The population contributed to this study were (92) EFL studenteducators, enrolled in the fourth level of the English Department, in the general and basic divisions at Port Said faculty of education in the first and second semesters of the academic year (2019-2020). For the purposes of the current study, the participating sample included only (59) EFL studenteducators enrolled in the basic division $(n=25,42.4 \%)$ and the general division $(n=34,57.6 \%)$. The majority of them were females $(n=46,78 \%)$, while the minority were males $(n=13,22 \%)$. The sample of the EFL student-educators contributed to this study were randomly assigned into two groups: (30) of EFL student-educators were randomly assigned as the control group, while (29) of EFL student-educators served as the experimental group. All participants in the two groups were Arabic native speakers. There ages ranged from $(20.1 / 21.4, M=18.7$, St, D.=0.38).

Table (3.1) shows the equivalence between the experimental and control groups extracted in the pre-application of the study instruments, in terms of age, reflective thinking skills; which were distributed into six dimensions, and attitudes toward the profession, which were distributed into five dimensions. It seems that there were no significant statistical differences between the participants of the two groups in terms of such variables in the pre- application of the study instruments, implying a relatively appropriate degree of equivalence between them. 
Korthagen's Onion Model and its Effectiveness in Developing Reflective Thinking Skills and Attitudes Toward the Profession among EFL Student-Educators

\begin{tabular}{|c|c|c|c|c|c|c|c|c|}
\hline \multicolumn{9}{|c|}{ Table 3.1: Equivalence between the Experimental and Control groups. } \\
\hline \multicolumn{2}{|c|}{ Variable } & Group & N. & Means & St. Dev. & DF. & $\begin{array}{l}\text { T. } \\
\text { Value }\end{array}$ & Sig. \\
\hline \multirow{2}{*}{\multicolumn{2}{|c|}{ AGE }} & Exp. & 29 & 18.88 & 0.3090 & \multirow[t]{2}{*}{57} & \multirow[t]{2}{*}{$\mathbf{0 . 8 5 0}$} & \multirow[t]{2}{*}{ Insignificant } \\
\hline & & Cont. & 30 & 18.77 & 0.4877 & & & \\
\hline \multirow{12}{*}{$\begin{array}{l}\text { Reflective } \\
\text { Thinking } \\
\text { Skills }\end{array}$} & \multirow[t]{2}{*}{ Contextual Skills } & Exp. & 29 & 10.655 & 0.7689 & \multirow[t]{2}{*}{57} & \multirow[t]{2}{*}{1.458} & \multirow[t]{2}{*}{ Insignificant } \\
\hline & & Cont. & 30 & 10.4000 & 0.5632 & & & \\
\hline & \multirow[t]{2}{*}{ Cognitive skills } & Exp. & 29 & 13.1034 & 0.7720 & \multirow[t]{2}{*}{57} & \multirow[t]{2}{*}{0.941} & \multirow[t]{2}{*}{ Insignificant } \\
\hline & & Cont. & 30 & 12.8000 & 0.5625 & & & \\
\hline & \multirow{2}{*}{$\begin{array}{l}\text { Self-Assessment } \\
\text { skills }\end{array}$} & Exp. & 29 & $\mathbf{1 0 . 3 7 9 3}$ & 1.0493 & \multirow[t]{2}{*}{57} & \multirow[t]{2}{*}{0.565} & \multirow[t]{2}{*}{ Insignificant } \\
\hline & & Cont. & 30 & 10.5000 & 0.5085 & & & \\
\hline & \multirow[t]{2}{*}{ Functional Skills } & Exp. & 29 & 12.6207 & $\mathbf{1 . 2 5 9 3 2}$ & \multirow[t]{2}{*}{57} & \multirow[t]{2}{*}{0.589} & \multirow[t]{2}{*}{ Insignificant } \\
\hline & & Cont. & 30 & 12.333 & 1.0854 & & & \\
\hline & \multirow[t]{2}{*}{ Ethical Skills } & Exp. & 29 & 12.7241 & 1.6881 & \multirow[t]{2}{*}{57} & \multirow[t]{2}{*}{0.529} & \multirow[t]{2}{*}{ Insignificant } \\
\hline & & Cont. & 30 & 12.933 & 1.3374 & & & \\
\hline & \multirow[t]{2}{*}{ Total } & Exp. & 29 & 59.4828 & 1.4298 & \multirow[t]{2}{*}{57} & \multirow[t]{2}{*}{0.996} & \multirow[t]{2}{*}{ Insignificant } \\
\hline & & Cont. & 30 & 58.9000 & 2.8205 & & & \\
\hline \multirow{10}{*}{$\begin{array}{l}\text { Attitudes } \\
\text { toward } \\
\text { Profession }\end{array}$} & Profession & Exp. & 29 & 13.6552 & 1.0098 & 57 & 0.481 & Insignificant \\
\hline & Significance & Cont. & 30 & $\mathbf{1 3 . 5 3 3 3}$ & 0.9371 & & & \\
\hline & Profession & Exp. & 29 & 12.8621 & 1.0930 & 57 & 0.259 & Insignificant \\
\hline & Future & Cont. & 30 & 12.8000 & 0.7144 & & & \\
\hline & EFL Teacher's & Exp. & 29 & 12.5862 & 1.6823 & 57 & 1.220 & Insignificant \\
\hline & Capabilities & Cont. & 30 & 12.7667 & 0.4302 & & & \\
\hline & Personal & Exp. & 29 & 13.0690 & 1.0667 & 57 & 0.679 & Insignificant \\
\hline & Abilities & Cont. & 30 & 13.2333 & 0.7739 & & & \\
\hline & Total & Exp. & 29 & 52.1724 & 2.2372 & 57 & 0.302 & Insignificant \\
\hline & & Cont. & 30 & 52.3333 & 1.8445 & & & \\
\hline
\end{tabular}

\subsection{Instruments}

The instruments used in this study were;

1- A scale on participants' reflective thinking skills.

2- A scale on participants' attitudes toward the profession.

All instruments used in this study were edited in the English language. They were prepared by the researcher in the light of the findings of related research, and presented to participants of the participating sample in a paper format.

3.4.1. The Scale on Reflective Thinking Skills for EFL Student-educators.

With concern to the study problem, the scale on participants' reflective thinking skills was prepared by the researcher, aiming to measure the development of these skills among the study participants owing to the use of the proposed training program based on the Onion model.

Further, the scale was prepared with concern to varied resources, including the scales proposed in previous related studies such as Malmir, A. (2018), Javadi \& Khatib (2014), Zeichner and Liston (2013), Choy \& Oo (2012), Akbari, Behzadpoor and Dadvand (2010), Dymoke and Harrison (2008), Sezer (2008), Muir and Beswick (2007), Taggart and Wilson (2005), 
د. ماجد محمدين

and Lee (2005). Adapting one of the scales proposed in previous related studies was not preferable due to many factors outside control, including inapplicability in the local Egyptian educational environment, extensive time required to fill out the scale, variation of the target population, scale instructions' lack of clarity, exaggerated number of items, and inadequate sequence of items. Added to previous related studies, the suggestions, comments and views offered by professors and assistant professors specialized in the fields of TEFL and Educational Psychology helped the researcher form better items. Furthermore, the researcher's personal expertise influenced the final wording of the scale items.

The scale generally consisted of two parts. The first part was made up of specific elements including participants' background information as well as an introduction to define its goal, general instructions on application method, and how a participant can record responses and data. In this regard, this part asked every participant to provide an informed consent to fill in the scale. Additionally, it was not allowed to reveal the participant's name or domicile in order to safeguard the participants' anonymity. The second part provided the items designed to elicit participants' reactions toward reflective thinking skills. The scale items were distributed as a 5point Likert scale (Always / Very Often / Sometimes / Rarely / Never). The degrees assigned were (5/4/3/ 2 / 1) respectively. The initial form of the scale included (52) items, calculated as a whole to obtain the total score of each participant, ranging between $(52 / 260)$ degrees. A higher score implies a high level of reflective thinking skills of EFL student-educators, and vice versa.

In the light of the layers of the onion model, the initial form of the scale items consisted of 52 items, distributed into six dimensions as follow:

1.Contextual Skills: Making sense of school context, culture and resources of time and space that can affect EFL teaching quality and its potential outcomes as well as the degree of students' EFL learning.

2. Cognitive skills: conscious efforts exerted to access to continuous learning opportunities and professional development resources.

3. Awareness of Actual learning Processes: actual act of reflection by the EFL student-educators to create better knowledge, and to accommodate for weaknesses.

4. Self-Assessment skills: actual act of reflection by the EFL studenteducators to recognize, realize, and be conscious of their personalities.

5. Functional Skills: deal with thinking skills desirable for the EFL studenteducator to reflect on their professional life as teachers of EFL.

6. Ethical Skills: deal with the skills desirable to realize, reason, and accept ethics and values such as justice, empathy, kindness, creativity and so forth. 
To help the scale items provide richer answers to the research questions, significant aspects were taken into consideration in the formulation and order of the scale items, including: to clearly explain the way of answering, the items were carefully and precisely worded, to use proper and simple items to avoid misunderstanding or potential confusion, to arrange the items in a reasonable sequence.

To ensure the scale validity, its initial form, consisting of (52) items of six dimensions, was submitted to an expert panel formed of (11) professors and assistant professors specialized in the fields of TEFL, Curricula \& Instruction, and Educational Psychology. Such a procedure was critical and meaningful to ensure that the scale is of high quality, the items are reliably observed and evaluated, and the scale is targeted to measure exactly and properly what is intended. The percentages agreement among the panel members ranged $(90.9 \%-100 \%)$ on all the scale items, suggesting that the scale items have relatively high validity. However, they provided some suggestions and modifications in terms of the scale length, items vagueness and appropriateness. All modifications suggested by the panel members were made including deleting (4) items in the scale because of its vagueness or overlapping with other items, in addition to merging (Awareness of Actual learning Processes) dimension by (Self-Assessment skills) dimension. Table 3.2 shows that only 48 items with five dimensions and degrees ranging between $(48$ / 240$)$, were included in the scale's final form.

Table 3.2: Distribution of Items in the Scale Final Form

\begin{tabular}{|c|c|c|}
\hline Dimensions of Skills & $\begin{array}{l}\text { Total of } \\
\text { Items }\end{array}$ & Items \\
\hline Contextual Skills & 9 & $1,2,3,4,5,6,7,8$, and 9 \\
\hline Cognitive skills & 10 & $10,11,12,13,14,15,16,17,18$, and 19. \\
\hline $\begin{array}{l}\text { Self-Assessment } \\
\text { skills }\end{array}$ & 8 & $20,21,22,23,24,25,26$, and 27 \\
\hline Functional Skills & 11 & $\begin{array}{l}28,29,30,31,32,33,34,35,36,37 \text {, and } \\
38 \text {. }\end{array}$ \\
\hline Ethical Skills & 10 & $39,40,41,42,43,44,45,46,47$, and 48. \\
\hline
\end{tabular}

To ensure the scale internal consistency, the correlation coefficients between the scale's total score, and the score of each skill included in the scale were calculated. As shown in table (3.3), all the correlation coefficients between the total score of the scale, and the score of each skill included in the scale were significant at $(\alpha \leq 0.01)$ level, suggesting that the scale items have relatively high internal consistency. 
Korthagen's Onion Model and its Effectiveness in Developing Reflective Thinking Skills and Attitudes Toward the Profession among EFL Student-Educators

د.

Table 3.3: Internal Consistency for the Scale

\begin{tabular}{|l|l|l|}
\hline The skills & $\begin{array}{l}\text { Total of } \\
\text { Items }\end{array}$ & $\begin{array}{l}\text { Correlation } \\
\text { Coefficients }\end{array}$ \\
\hline Contextual Skills & 9 & $\mathbf{9 . 7 8}$ \\
\hline Cognitive skills & 10 & $\mathbf{0 . 6 8}$ \\
\hline $\begin{array}{l}\text { Self-Assessment } \\
\text { skills }\end{array}$ & $\mathbf{8}$ & $\mathbf{0 . 7 6}$ \\
\hline Functional Skills & 11 & $\mathbf{0 . 6 9}$ \\
\hline Ethical Skills & $\mathbf{1 0}$ & $\mathbf{0 . 6 4}$ \\
\hline
\end{tabular}

To ensure the scale reliability, Cronbach's alpha for the total score of the scale and for all the five dimensions of skills were computed. The alpha coefficients were 0.68 for contextual skills, 0.69 for cognitive skills, 0.71 for self-assessment skills, 0.70 for functional skills, 0.70 for ethical skills, and 0.73 for the total score of the scale. Looking at the values mentioned, it is evident that all the alpha coefficients were positive ones, implying the scale items and dimensions have relatively high reliability.

Furthermore, the Test-Retest Reliability was used. The scale was applied on a pilot sample including (50) student-educators out of the main study sample. Then, the scale was reapplied on the same sample after two weeks. A colleague, previously trained on the scale, helped the researcher in applying / reapplying the scale during the pilot study. Using such a method was critical to ensure that the scale is representative and stable over time. The correlation coefficients among the first and the second application and the scale total score were $\mathbf{0 . 7 6}$ for contextual skills, $\mathbf{0 . 7 7}$ for cognitive skills, 0.75 for self-assessment skills, 0.80 for functional skills, 0.80 for ethical skills, and 0.82 for the total score of the scale. Looking at the aforementioned values, it is evident that all the correlation coefficients were positive ones, implying the scale items have relatively high reliability.

3.4.2 The Scale on Participants' Attitudes toward the Profession.

The aim of this scale was to identify the development of EFL studenteducators' attitudes toward the EFL teaching profession among the study participants owing to the use of the proposed training program based on the Onion model. Investigating such attitudes is significant because of their serious role in intensifying and boosting knowledge and skills appropriate to EFL teaching.

In this regard, this scale was prepared with concern to the scales proposed in past literature, including Andronache (2013), Alkhateeb (2013), Potolea \& Toma (2010), Tezci \& Terzi (2010), Gonzalez, et al. (2008), Brown, \& Slate, (2008), Bocos (2008), Ustuner (2006), and Dooley, et al. (2004). Although these related studies have made great contributions in this concern, it was preferred to develop a new scale for the fear of their scales' unsuitability for application in a local Egyptian educational environment. Additionally, some colleagues specialized in the fields of TEFL and 


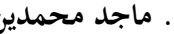

Educational Psychology at Port Said faculty of education provided considerable suggestions and comments that were very helpful.

In general, a 2-part scale was used for achieving the current research purposes. The first part required participants to provide diverse background information, such as their names (optional), gender, age, and so forth. The second part provided the study participants items designed to elicit their perspectives regarding their profession as EFL future potential teachers. The initial proposed scale included a series of 48 items. A Likert scale with 3 points (Always / Sometimes / Rarely) was used. The degrees assigned were $(3 / 2$ / 1) respectively, calculated as a whole to obtain the total score of each participant, ranging between $(48 / 144)$ degrees. A higher score indicates a high level of attitude towards the profession among EFL student-educators, and vice versa. The aim of the proposed scale was to evaluate the level of four main dimensions of EFL student-educators' attitudes toward EFL teaching profession, as follow:

1- Personal perspective of the profession significance,

2- Personal perspective of the profession future,

3- Personal estimation of EFL teacher's capabilities, and

4- Personal estimation of his/ her own abilities required for the profession.

To help the scale achieve its intended purposes, the following were considered: (1) to clearly explain the way of answering, (2) the items were carefully and precisely worded, (3) to use proper items to avoid misunderstanding or potential confusion, and (4) to arrange the items in a reasonable sequence.

To help establish the scale face and content validity, the initial form, consisting of (48) items of four dimensions, was reviewed by an expert panel of eleven education experts in the fields of TEFL, Curricula \& Instruction, and Educational Psychology in terms of items' quality, clarity, preciseness, sequence, suitableness, and potential to measure exactly and properly what is intended. The percentages agreement among the panel members ranged $(87.5 \%-100 \%)$ on all the scale items, implying the scale items have relatively high validity. According to the panel's feedback, views and suggestions, the scale was revised, refined and modified to form its final form with 44 items (as 4 items were deleted), four dimensions, and a score ranging between $(44 / 132)$ degrees of each participant, as shown in table (3.4). 
Korthagen's Onion Model and its Effectiveness in Developing Reflective Thinking Skills and Attitudes Toward the Profession among EFL Student-Educators

د. د. ماجد محمدين

Table 3.4: Distribution of Items in the Scale Final Form

\begin{tabular}{|c|c|c|}
\hline Dimensions of Attitude & $\begin{array}{l}\text { Total of } \\
\text { Items }\end{array}$ & Items \\
\hline Profession Significance & 12 & $\begin{array}{l}1,6,9,12,14,17,18,22,25,26,29, \\
\text { and } 30\end{array}$ \\
\hline Profession Future & 11 & $\begin{array}{l}2,7,10,11,13,15,16,21,23,27, \text { and } \\
35\end{array}$ \\
\hline $\begin{array}{ll}\text { EFL } & \text { Teacher's } \\
\text { Capabilities } & \\
\end{array}$ & 10 & $3,8,19,20,24,31,36,38,41$, and 42 \\
\hline Personal Abilities & 11 & $\begin{array}{l}4,5,28,32,33,34,37,39,40,43 \text {, and } \\
44\end{array}$ \\
\hline
\end{tabular}

To ensure the scale internal consistency, the correlation coefficients between the degree of each item and the total score of the dimension it belongs to were computed. The alpha coefficients ranged from 0.75 to 0.77 for the (Profession Significance) dimension, from 0.72 to 0.76 for the (Profession Future) dimension, from 0.74 to 0.80 for the (EFL Teacher's Capabilities) dimension, and from 0.70 to 0.75 for the (Personal Abilities) dimension. Added to this, the correlation coefficients between the degree of each dimension and the total score of the scale were $(0.79$ / 0.78 / 0.82 / 0.80) respectively. Such values were significant at $(\alpha \leq 0.01)$ level, implying the scale items and dimensions have relatively high internal consistency.

To ensure the scale reliability, the computed alpha coefficients were 0.78 for the (Profession Significance) dimension, 0.77 for the (Profession Future) dimension, 0.75 for the (EFL Teacher's Capabilities) dimension, 0.79 for the (Personal Abilities) dimension, and 0.80 for the total score of the scale; implying that the scale items and dimensions have relatively high reliability.

Furthermore, the Test-Retest Reliability was computed to ensure that the scale is representative and stable over time by applying the scale to a pilot sample including (50) student-educators out of the main study sample, and reapplying it on the same sample after two weeks with help from a colleague previously trained. The computed correlation coefficients were 0.75 for the (Profession Significance) dimension, 0.76 for the (Profession Future) dimension, 0.81 for the (EFL Teacher's Capabilities) dimension, 0.75 for the (Personal Abilities) dimension, and 0.83 for the total score of the scale; implying that the scale items and dimensions have relatively high reliability.

3.5 The Proposed Training Program based upon the Onion Model.

The proposed training program based upon the Onion model was designed to provide the optimal learning experiences for EFL studenteducators necessary to help them reflect on and evaluate their teaching, and seek alternatives required to achieve their intended goals, ensure student learning and weaken negative attitudes toward their profession as EFL 
د. ماجد محمدين

teachers. Such a design stood on this study objectives, the research population, and the findings of related research such as Ashrafi, et al. (2020), Nur \& Cephe (2017), Korthagen (2017), (2016), and (2014) in additon to Korthagen \& Vasalos (2010) and (2005).

Appendix (D) presents a comprehensive report of the program design.

To help establish face and content validity, the proposed program based upon the Onion model was reviewed by an expert panel of eleven education experts in the fields of TEFL, Curricula \& Instruction, and Educational Psychology in terms of items and components quality, clarity, preciseness, sequence, suitableness, and potential to achieve exactly what is intended. The expert panel assured the overall appearance and the relevancy of items and components of the proposed program.

\subsection{Study Procedures}

The consequent procedures were followed to investigate the effect of the proposed training program based upon the Onion model on developing reflective thinking skills and attitudes towards the profession among EFL student-educators at Port Said Faculty of Education:

I. Before using the instruments to collect data, a pilot survey on a group of EFL student-educators $(\mathrm{N}=50)$, that is representative of the target one, was conducted to ensure the scales' face and content validity, internal consistency, reliability, Test-Retest reliability.

II. The target EFL student-educators sample was divided into two groups: a control group $(\mathrm{N}=30)$, and an experimental group $(\mathrm{N}=29)$.

III. The scale on participants' reflective thinking skills and the scale on participants' attitudes toward the profession, were pre-applied on both the control group and the experimental group.

IV. The proposed training program based upon the Onion model included (20) sessions, was implemented for (10) weeks on the experimental group in the first semester of the academic year 2019/ 2020. Appendix (D) shows sequencing of these sessions. In this regard, the following aspects were considered by the researcher during the implementation of the proposed training program:

1- An overview of the instruments, objectives and content of the proposed program was provided to the trainees.

2- A printed copy of the program contents and the trainee handout was presented to each trainee.

3- Getting trainees acquainted with the activities and tasks was considered.

4- The program timetable set was respected.

5- The scheduled sequence of the proposed program contents, tasks and activities was abided by the researcher. 


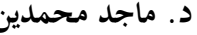

6- A theoretical analysis of the targeted reflective thinking skills and attitudes toward profession was provided to trainees.

7- A sequence of instructions on the implementation of activities, tasks and drills was delivered to trainees.

8- Effective presentations in PowerPoint were used to display important information and tips.

V. The scale on participants' reflective thinking skills and the scale on participants' attitudes toward the profession, were post-applied on both the control group and the experimental group.

VI. After two months, the scale on participants' reflective thinking skills and the scale on participants' attitudes toward the profession, were reapplied on the experimental group only as a follow-up investigation.

VII. Data of the post- and follow-up applications of the scales were collected and statistically analyzed using SPSS.V22.0. in addition to Independent and Paired Samples T. Tests.

IV. Findings and Conclusion

This part sets out to discuss the study findings, significance, implications for EFL teaching practice, recommendations and suggestions for future research.

\subsection{Findings and Discussions}

The following findings of are outlined in accordance with the research hypotheses:

\subsubsection{Results related to the First Hypothesis:}

The first hypothesis states, "There are significant statistical differences at $(\alpha \leq 0.01)$ level between the experimental group's mean scores and the control group's mean scores in the post- application of the scale on participants' reflective thinking skills in favor of the experimental group students". To verify it, the mean scores, standard deviations and $T$. value of both the experimental and control groups in the post- application of the scale on participants' reflective thinking skills were computed using Independent Samples T. Test, as shown in Table (4.1). Furthermore, as also shown in table (4.1), the size effect of the proposed training program based upon the Onion model on dependent variables was computed. 
Korthagen's Onion Model and its Effectiveness in Developing Reflective Thinking

Skills and Attitudes Toward the Profession among EFL Student-Educators

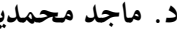

Table (4.1): Mean scores, standard deviations and T. value of the experimental and control groups in the post- application of the scale on participants' reflective thinking skills.

\begin{tabular}{|c|c|c|c|c|c|c|c|c|c|c|}
\hline \multicolumn{2}{|l|}{ Variable } & Group & N. & Means & St. Dev. & DF. & $\begin{array}{l}\text { T. } \\
\text { Value }\end{array}$ & Level & $\begin{array}{l}\eta 2 . \\
\text { Value }\end{array}$ & $\begin{array}{l}\text { Size } \\
\text { Effect }\end{array}$ \\
\hline \multirow{12}{*}{$\begin{array}{l}\text { Reflectiv } \\
\text { e } \\
\text { Thinkin } \\
\text { g Skills }\end{array}$} & \multirow{2}{*}{$\begin{array}{l}\text { Contextual } \\
\text { Skills }\end{array}$} & Cont. & 30 & 17.0690 & 1.667 & \multirow[t]{2}{*}{57} & \multirow[t]{2}{*}{19.017} & \multirow[t]{2}{*}{0.01} & \multirow[t]{2}{*}{0.86} & \multirow[t]{2}{*}{ Large } \\
\hline & & Exp. & 29 & 28.567 & 2.8123 & & & & & \\
\hline & \multirow{2}{*}{$\begin{array}{l}\text { Cognitive } \\
\text { skills }\end{array}$} & Cont. & 30 & 16.9310 & 2.0166 & \multirow[t]{2}{*}{57} & \multirow[t]{2}{*}{19.095} & \multirow[t]{2}{*}{0.01} & \multirow[t]{2}{*}{0.82} & \multirow[t]{2}{*}{ Large } \\
\hline & & Exp. & 29 & 29.933 & 3.0843 & & & & & \\
\hline & \multirow{2}{*}{$\begin{array}{l}\text { Self- } \\
\text { Assessment } \\
\text { skills }\end{array}$} & Cont. & 30 & 15.6897 & 3.5667 & \multirow[t]{2}{*}{57} & \multirow[t]{2}{*}{10.231} & \multirow[t]{2}{*}{0.01} & \multirow[t]{2}{*}{0.64} & \multirow{2}{*}{$\begin{array}{l}\text { Mediu } \\
\text { m }\end{array}$} \\
\hline & & Exp. & 29 & 24.9333 & 3.3726 & & & & & \\
\hline & \multirow{2}{*}{$\begin{array}{l}\text { Functional } \\
\text { Skills }\end{array}$} & Cont. & 30 & 17.7931 & 2.8832 & \multirow[t]{2}{*}{57} & \multirow[t]{2}{*}{16.604} & \multirow[t]{2}{*}{0.01} & \multirow[t]{2}{*}{0.76} & \multirow[t]{2}{*}{ Large } \\
\hline & & Exp. & 29 & 30.333 & 2.9165 & & & & & \\
\hline & \multirow[t]{2}{*}{ Ethical Skills } & Cont. & 30 & 16.4483 & 3.1463 & \multirow[t]{2}{*}{57} & \multirow[t]{2}{*}{13.548} & \multirow[t]{2}{*}{0.01} & \multirow[t]{2}{*}{3.59} & \multirow{2}{*}{$\begin{array}{l}\text { Mediu } \\
\text { m }\end{array}$} \\
\hline & & Exp. & 29 & 29.233 & 4.0316 & & & & & \\
\hline & \multirow[t]{2}{*}{ Total } & Cont. & 30 & 83.9310 & 6.2274 & \multirow[t]{2}{*}{57} & \multirow[t]{2}{*}{24.341} & \multirow[t]{2}{*}{0.01} & \multirow[t]{2}{*}{0.91} & Large \\
\hline & & Exp. & 29 & 143.000 & 11.5430 & & & & & \\
\hline
\end{tabular}

As shown in Table (4.1), There are significant statistical differences at ( $\alpha$ $\leq 0.01$ ) level between the experimental group's mean scores and the control group's mean scores in the post- application of the scale on participants' reflective thinking skills in favor of the experimental group students, as $T$. value is (24.341), statistically significant at $(\alpha \leq 0.01)$ level. Also, $\eta$. value and the total size effect of the proposed training program is (0.91), implying effectiveness of the proposed program in developing participants' reflective thinking skills in the post- application.

This finding corroborates the findings of other research studies that approved the actualization of the core reflection approach, in general, and the onion model, in special, in developing enhancing skills of reflection, creativity and innovation, including the findings of the research studies conducted by Ashrafi, et al. (2020), Nur \& Cephe, (2017), and Korthagen (2017); indicating that developing reflective thinking skills is a prerequisite for the quality of EFL teaching. In this regard, this finding can be attributed to the kind of training method. Traditional practices for training EFL student-educators were found to have little effect on EFL studenteducators' ability to reflect on their teaching process and overcome their problems that might determine their EFL classroom actions. These traditional practices have not helped EFL student-educators develop the necessary reflective thinking skills to cope with their EFL teaching challenges. However, Attending the sessions of the proposed training program based on the onion model helped the participating EFL studenteducators to pass through a remarkable effective change of their reflective thinking skills. The proposed program based on the onion model gave space for the EFL student-educators to consider, reconsider, think reflectively on 
professional context- related factors that might determine their actual classroom actions, their beliefs and identities as EFL teachers, how EFL teachers teach best, and who the ideal EFL teacher is.

\subsubsection{Results related to the Second Hypothesis:}

The second hypothesis states, "There are significant statistical differences at $(\alpha \leq 0.01)$ level between the experimental group's mean scores and the control group's mean scores in the post- application of the scale on participants' attitudes toward the profession in favor of the experimental group students". To verify such a hypothesis, the mean scores, standard deviations and $T$. value of both the experimental and control groups in the post- application of the scale on participants' participants' attitudes toward the profession were computed using Independent Samples T. Test, as shown in Table (4.2). Furthermore, as also shown in table (4.2), the size effect of the proposed training program based upon the Onion model on dependent variables was computed.

As shown in Table (4.2), There are significant statistical differences at ( $\alpha$ $\leq 0.01$ ) level between the experimental group's mean scores and the control group's mean scores in the post- application of the scale on participants' attitudes toward the profession in favor of the experimental group students, as $T$. value is (35.420), statistically significant at $(\alpha \leq 0.01)$ level. Also, $\eta$. value and the total size effect of the proposed training program is $(0.95)$, a large one implying effectiveness of the proposed program in developing participants' attitudes toward the profession in the post- application.

Table (4.2): Mean scores, standard deviations and $T$. value of the experimental and control groups in the post- application of the scale on participants' attitudes toward the profession.

\begin{tabular}{|c|c|c|c|c|c|c|c|c|c|c|}
\hline \multicolumn{2}{|l|}{ Variable } & Group & N. & Means & St. & DF. & & Level & & \\
\hline \multirow{10}{*}{$\begin{array}{l}\text { Attitudes } \\
\text { toward } \\
\text { the } \\
\text { Professio } \\
\text { n }\end{array}$} & \multirow{2}{*}{$\begin{array}{l}\text { Profession } \\
\text { Significance }\end{array}$} & Cont. & 30 & 17.433 & 1.2507 & \multirow[t]{2}{*}{57} & \multirow{2}{*}{19.360} & \multirow{2}{*}{0.01} & \multirow[t]{2}{*}{0.86} & \multirow{2}{*}{$\begin{array}{l}\text { Larg } \\
\text { e }\end{array}$} \\
\hline & & Exp. & 29 & 24.379 & 1.497 & & & & & \\
\hline & \multirow{2}{*}{$\begin{array}{l}\text { Profession } \\
\text { Future }\end{array}$} & Cont. & 30 & 15.5 & 1.008 & \multirow[t]{2}{*}{57} & \multirow[t]{2}{*}{22.389} & \multirow[t]{2}{*}{0.01} & \multirow[t]{2}{*}{0.89} & \multirow{2}{*}{$\begin{array}{l}\text { Larg } \\
\text { e }\end{array}$} \\
\hline & & Exp. & 29 & 22.310 & 1.312 & & & & & \\
\hline & \multirow{2}{*}{$\begin{array}{l}\text { EFL } \\
\text { Teacher's } \\
\text { Capabilities }\end{array}$} & Cont. & 30 & 15.933 & 0.639 & \multirow[t]{2}{*}{57} & \multirow[t]{2}{*}{7.887} & \multirow[t]{2}{*}{0.01} & \multirow[t]{2}{*}{0.52} & \multirow{2}{*}{$\begin{array}{l}\text { Medi } \\
\text { um }\end{array}$} \\
\hline & & Exp. & 29 & 18.793 & 1.988 & & & & & \\
\hline & \multirow{2}{*}{$\begin{array}{l}\text { Personal } \\
\text { Abilities }\end{array}$} & Cont. & 30 & 15.5 & 1.634 & \multirow[t]{2}{*}{57} & \multirow[t]{2}{*}{21.760} & \multirow[t]{2}{*}{0.01} & \multirow[t]{2}{*}{0.89} & \multirow{2}{*}{$\begin{array}{l}\text { Larg } \\
\text { e }\end{array}$} \\
\hline & & Exp. & 29 & 23.966 & 1.291 & & & & & \\
\hline & \multirow[t]{2}{*}{ Total } & Cont. & 30 & 64.4 & 2.736 & \multirow[t]{2}{*}{57} & \multirow[t]{2}{*}{35.420} & \multirow[t]{2}{*}{0.01} & \multirow[t]{2}{*}{0.95} & \multirow{2}{*}{$\begin{array}{l}\text { Larg } \\
\text { e }\end{array}$} \\
\hline & & Exp. & 29 & 89.379 & 2.678 & & & & & \\
\hline
\end{tabular}

This finding corroborates the findings of other research studies arguing that reflection enables student- educators to foster their attitudes that value 


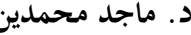

the personal and interpersonal growth, including the findings of the research studies conducted by Nurfaidah (2018), De Matos (2014), Marzuki (2013), Farrell (2012), Ho (2009), Rodgers (2002). These aforementioned studies indicated that training teachers of English to reflect helps cultivate their responsibility towards whatever issues and problems they face in the context of their EFL instruction. A possible interpretation of this finding might be that the difference between traditional practices and the proposed training program based on the onion model. It is apparent that, before attending the program, the participating EFL student-educators experienced negative attitudes toward their profession, making it impossible for them to make use of their full potential in their EFL teaching practice. Traditional practices for training EFL student-educators were found to have little effect on their ability to minimize these negative effects experienced in traditional activities. However, the proposed training program based on the onion model, with its exterior layers (i.e., environment $\&$ behavior) expanding from the surface to the interior ones (i.e., identity \& mission) stimulated them to focus on their strengths as EFL teachers and be totally involved in their field teaching practice, keeping desire throughout their teaching practice. Another possibility is that the proposed training program based on the onion model was presented to the participating EFL student-educators with great care, adequate support and feedback, time, materials, resources, activities, tasks and methods for refection, helping them stay interested, focused and enthusiastic in teaching EFL.

\subsubsection{Results related to the Third Hypothesis:}

The third hypothesis states, "There are not significant statistical differences between the experimental group students' mean scores in the post-application and their mean scores in the follow-up application of the scale on reflective thinking skills". To verify such a hypothesis, the mean scores, standard deviations and $T$. value of both the post- application and the follow-up application of the scale on participants' reflective thinking skills were computed using Paired T. Test, as shown in Table (4.3).

Table (4.3): Mean scores, standard deviations and $T$. value of the experimental group students in the post- and the follow-up applications of the scale on participants' reflective thinking skills.

\begin{tabular}{|c|c|c|c|c|c|c|c|c|}
\hline \multicolumn{2}{|l|}{ Variable } & $\begin{array}{l}\text { Measureme } \\
\text { n }\end{array}$ & N. & Means & $\begin{array}{l}\text { St. } \\
\text { Dev. }\end{array}$ & DF. & $\begin{array}{l}\text { T. } \\
\text { Value }\end{array}$ & $\begin{array}{l}\text { Significanc } \\
\text { e }\end{array}$ \\
\hline \multirow{5}{*}{$\begin{array}{l}\text { Reflecti } \\
\text { ve }\end{array}$} & \multirow{2}{*}{$\begin{array}{l}\text { Contextual } \\
\text { Skills }\end{array}$} & Post & 29 & 28.567 & 2.8123 & \multirow[t]{2}{*}{28} & \multirow[t]{2}{*}{0.593} & \multirow{2}{*}{$\begin{array}{l}\text { Insignifican } \\
\text { t }\end{array}$} \\
\hline & & Follow & 29 & 28.301 & 2.5649 & & & \\
\hline & \multirow{2}{*}{$\begin{array}{l}\text { Cognitive } \\
\text { skills }\end{array}$} & Post & 29 & 29.933 & 3.0843 & \multirow[t]{2}{*}{28} & \multirow[t]{2}{*}{1.281} & \multirow{2}{*}{$\begin{array}{l}\text { Insignifican } \\
t\end{array}$} \\
\hline & & Follow & 29 & $\begin{array}{l}29.379 \\
3\end{array}$ & 2.6378 & & & \\
\hline & Self- & Post & 29 & 24.933 & $\mathbf{3 . 3 7 2 6}$ & 28 & 1.386 & Insignifican \\
\hline
\end{tabular}


Korthagen's Onion Model and its Effectiveness in Developing Reflective Thinking Skills and Attitudes Toward the Profession among EFL Student-Educators

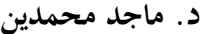

\begin{tabular}{|c|c|c|c|c|c|c|c|c|}
\hline \multirow{8}{*}{$\begin{array}{l}\text { Thinkin } \\
\text { g Skills }\end{array}$} & \multirow{2}{*}{$\begin{array}{l}\text { Assessment } \\
\text { skills }\end{array}$} & & & 3 & & & & \multirow[t]{2}{*}{$\mathbf{t}$} \\
\hline & & Follow & 29 & $\begin{array}{l}24.344 \\
8\end{array}$ & 2.1921 & & & \\
\hline & \multirow{2}{*}{$\begin{array}{l}\text { Functional } \\
\text { Skills }\end{array}$} & Post & 29 & 30.333 & 2.9165 & \multirow[t]{2}{*}{28} & \multirow[t]{2}{*}{0.757} & \multirow{2}{*}{$\begin{array}{l}\text { Insignifican } \\
\mathbf{t}\end{array}$} \\
\hline & & Follow & 29 & $\begin{array}{l}30.448 \\
3\end{array}$ & 2.5012 & & & \\
\hline & \multirow[t]{2}{*}{ Ethical Skills } & Post & 29 & 29.233 & 4.0316 & \multirow[t]{2}{*}{28} & \multirow[t]{2}{*}{1.612} & \multirow{2}{*}{$\begin{array}{l}\text { Insignifican } \\
\mathbf{t}\end{array}$} \\
\hline & & Follow & 29 & 29.201 & 3.6752 & & & \\
\hline & \multirow[t]{2}{*}{ Total } & Post & 29 & $\begin{array}{l}143.00 \\
0\end{array}$ & $\begin{array}{l}11.543 \\
0\end{array}$ & \multirow[t]{2}{*}{28} & \multirow[t]{2}{*}{0.611} & \multirow[t]{2}{*}{$\begin{array}{l}\text { Insignifican } \\
\mathbf{t}\end{array}$} \\
\hline & & Follow & 29 & $\begin{array}{l}142.17 \\
2\end{array}$ & $\begin{array}{l}10.135 \\
8\end{array}$ & & & \\
\hline
\end{tabular}

As shown in Table (4.3), there are not significant statistical differences between the experimental group students' mean scores in every dimension of reflective thinking skills; and their total scores in the post- and the follow-up applications of the scale on reflective thinking skills, implying the continuality of the proposed program effectiveness in developing reflective thinking skills.

This finding corroborates the findings of related literature that training on reflection and related skills ensures that EFL novice and experienced teachers get the best possible EFL teaching experience, including other research studies conducted by Chang (2019), Hussein (2018), Cavilla (2017), Sööt \& Viskus (2015), Black (2015), Fatemipour \& Hosseingholikhani (2014), and Liu \& Zhang (2014). A possible interpretation of this finding might be that the proposed training program based on the onion model provided the participating EFL student-educators with significant experiences that is vital to the EFL teaching process. It enabled them to connect previous learning experiences, focus on their personal strengths and weaknesses, become aware of the skills they have or have not developed. In that context, the participating EFL student-educators had an opportunity to apply these experiences in directing their own teaching and improve on their future instruction performance. With the passage of time, they found EFL teaching as an engaging and interactive experience.

\subsubsection{Results related to the Fourth Hypothesis:}

The fourth hypothesis states, "There are not significant statistical differences between the experimental group students' mean scores in the post-application and their mean scores in the follow-up application of the scale on attitudes toward profession". To verify such a hypothesis, the mean scores, standard deviations and $T$. value of both the post- application and the follow-up application of the scale on participants' attitudes toward the profession were computed using Paired T. Test, as shown in Table (4.4). 
Korthagen's Onion Model and its Effectiveness in Developing Reflective Thinking

Skills and Attitudes Toward the Profession among EFL Student-Educators

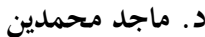

Table (4.4): Mean scores, standard deviations and T. value of the experimental group students in the post- and the follow-up applications of the scale on participants' attitudes toward profession.

\begin{tabular}{|c|c|c|c|c|c|c|c|c|}
\hline \multicolumn{2}{|l|}{ Variable } & Measureme & N. & Means & St. & DF. & & Sig. \\
\hline \multirow{10}{*}{$\begin{array}{l}\text { Attitudes } \\
\text { toward } \\
\text { the } \\
\text { Professio } \\
\text { n }\end{array}$} & \multirow{2}{*}{$\begin{array}{l}\text { Profession } \\
\text { Significance }\end{array}$} & Post & 29 & 24.379 & 1.497 & \multirow{2}{*}{57} & \multirow{2}{*}{1.388} & \multirow{2}{*}{$\begin{array}{l}\text { Insignifica } \\
\text { nt }\end{array}$} \\
\hline & & Follow & 29 & 23.413 & 4.187 & & & \\
\hline & \multirow{2}{*}{$\begin{array}{l}\text { Profession } \\
\text { Future }\end{array}$} & Post & 29 & 22.310 & 1.312 & \multirow[t]{2}{*}{57} & \multirow[t]{2}{*}{1.185} & \multirow{2}{*}{$\begin{array}{l}\text { Insignifica } \\
\text { nt }\end{array}$} \\
\hline & & Follow & 29 & 33.103 & 1.397 & & & \\
\hline & \multirow{2}{*}{$\begin{array}{l}\text { EFL Teacher's } \\
\text { Capabilities }\end{array}$} & Post & 29 & 18.793 & 1.988 & \multirow[t]{2}{*}{57} & \multirow[t]{2}{*}{1.154} & \multirow{2}{*}{$\begin{array}{l}\text { Insignifica } \\
\text { nt }\end{array}$} \\
\hline & & Follow & 29 & 18.620 & 2.77 & & & \\
\hline & \multirow{2}{*}{$\begin{array}{l}\text { Personal } \\
\text { Abilities }\end{array}$} & Post & 29 & 23.966 & 1.291 & \multirow[t]{2}{*}{57} & \multirow[t]{2}{*}{1.651} & \multirow{2}{*}{$\begin{array}{l}\text { Insignifica } \\
\text { nt }\end{array}$} \\
\hline & & Follow & 29 & 23.689 & 1.560 & & & \\
\hline & \multirow[t]{2}{*}{ Total } & Post & 29 & 89.379 & 2.678 & \multirow[t]{2}{*}{57} & \multirow[t]{2}{*}{1.440} & \multirow{2}{*}{$\begin{array}{l}\text { Insignifica } \\
\text { nt }\end{array}$} \\
\hline & & Follow & 29 & 89.103 & 2.907 & & & \\
\hline
\end{tabular}

As shown in Table (4.4), there are not significant statistical differences between the experimental group students' mean scores in every dimension of attitudes toward the profession; and their total scores in the post- and the follow-up applications of the scale on attitudes toward profession, implying the continuality of the proposed program effectiveness in developing attitudes toward the EFL profession.

This finding supports the positions proposed by Ashrafi, et al. (2020), Korthagen \& Nuijten (2017), Korthagen (2017), Korthagen, Kim, \& Greene (2013), Borg (2011), Putney \& Broughton (2010), and Pacheco (2005) that the onion model can be a reasonable source for developing positive attitudinal change among EFL novice and experienced teachers because it offers a significant opportunity to reflect on the teaching environment and experience. A possible interpretation of this finding might be that traditional practices of EFL teaching practices cultivated negative feelings of frustration, demotivation, and lack of self-confidence. On the other hand, the proposed training program based on the onion model was found to have an effective impact on the participating EFL student-educators. It was presented with adequate materials, significant activities, and considerable tasks that helped the study participants achieve better outcomes and identify opportunities to improve their teaching performance and how to hand the teaching process of EFL differently.

Overall, this study revealed promising results, indicating that attending the sessions of the proposed training program based on the onion model helped the participating EFL student-educators to pass through a remarkable effective change of their reflective thinking skills and attitudes toward their profession. This corroborates the findings of related literature that confirms the efficiency and actualization of the onion model in 
و. ماجد محمدين

enhancing reflection, potentials, ideals and attitudes, including the findings of the research studies conducted by Ashrafi, et al. (2020), Korthagen \& Nuijten (2017), Korthagen (2017), Korthagen, Kim, \& Greene (2013), Borg (2011), Putney \& Broughton (2010), and Pacheco (2005). Added to this, the researcher' experience in conducting this study suggests the onion model, with its exterior layers (i.e., environment \& behavior) expanding from the surface to the interior ones (i.e., identity \& mission) could be a significant resource to stimulate EFL student-educators to focus on their strengths; and to promote their professional growth as EFL potentials teachers.

\subsection{Implications}

This study will be of interest to EFL supervisors, student-educators, novice and experienced teachers, and researchers who would like to get benefit from a recent strict research in the EFL field. The findings of this study provide insights into the nature of EFL teaching practice and reflection. It also has impacts on theoretical and methodological assumptions of university policy and curricula makers about the onion model and its significant role in developing reflective thinking skills and attitudes toward the EFL profession, prevailed in EFL teacher education programs in university. It has shown the importance of understanding of teacher environment, behaviors, beliefs, identity, and morals as influential variables in the EFL context. This may help EFL teachers who seek to adjust their methods and techniques in order to keep up with variables of the EFL contexts where they teach. Added to that, the results of this study yielded evidence in advancing our understanding of EFL contextual requirements and EFL teachers' need to be flexible and adopt themselves to varied circumstances.

\subsection{Delimitations}

This study, in a certain extent, provided insight of reflective thinking skills and attitudes of EFL student-educators in their teaching practice. For this reason, generalizations cannot be made for the whole EFL teachers. Another limitation is that to investigate EFL student-educators' reflective thinking skills and attitudes toward their profession, this study was confined to two groups of EFL student-educators $(N=59)$ enrolled at the fourth level of English department at Port Said faculty of education. It would be better investigating such variables of a larger number of EFL student-educators enrolling at other education faculties located in various Egyptian cities. A third limitation is that the instruments of this study were confined to two scales for data collection. Both are designed according to Likert-type items in order to elicit the participants' perspectives about reflective thinking skills and attitudes toward their EFL profession. It would be better investigating such variables using other instruments. A 
د. ماجد محمدين

fourth limitation is that this study is confined to investigating the attitudes toward their EFL profession of two groups of EFL studenteducators. It would be better investigating such attitudes among novice and experienced EFL teachers in the light of other influential variables such as age or gender.

\subsection{Suggestions for Further Research}

On the basis of the findings of this study, the following suggestions may be put forth:

- To investigate the effectiveness of the Onion model on developing EFL writing and comprehension skills.

- To investigate the underlying reasons of the discrepancies among theoretical and practical aspects of EFL teaching practice.

- To apply the study instruments with a larger sample of EFL teachers.

\subsection{Recommendations}

On the basis of the findings of this study, the following recommendations may be put forth: an obligatory test should be conducted before the recruitment of the EFL teachers; education policy makers should consider the basic contextual factors beliefs, needs and requirements of EFL teachers that determine their teaching actual performance; and to find the adequate and proper ways of supporting inexperienced EFL teachers.

\subsection{Conclusion}

The most important goal of this study was to find an effective way for supporting EFL student-educators experiencing low reflective thinking skills and attitudinal decline toward their EFL profession. To achieve this goal, two scales were used to measure reflective thinking skills and their attitudes toward the EFL profession among the study participants who were trained on the onion model for reflection. The proposed training program was presented with adequate materials, significant activities, and considerable tasks. Overall, the four hypotheses put forward in the current study were borne out. The results seem to indicate that the use of the proposed training program based on the onion model has a substantial impact on the participating EFL student-educators' reflective thinking skills and their attitudes toward the EFL profession. In this study, traditional practices of EFL teaching practice were compared with practices included in the proposed training program based on the onion model, and the latter were clearly far ahead in this respect. A possible interpretation of this could lie in the fact that the onion model, known as one of the influential novelties of the Core Reflection approach, with its exterior layers expanding from the surface to the interior ones, provides more meaningful opportunities to the EFL student-educators' to reflect on and focus on their strengths as EFL teachers and be totally involved in their field teaching practice. These aspects were supported by varied related 
Korthagen's Onion Model and its Effectiveness in Developing Reflective Thinking Skills and Attitudes Toward the Profession among EFL Student-Educators

د. ماجد محمدين.

study including the studies undertaken by Ashrafi, et al. (2020), Nur \& Cephe, (2017), and Korthagen (2017). Added to this, one of the main advantages the onion model offers to EFL student-educators is that it helps them avoid attitudinal decline towards their profession. This advantage was observed in related research studies such as Korthagen (2017), Korthagen, Kim, \& Greene (2013), Borg (2011), Putney \& Broughton (2010). 


\section{References}

Abdolrezapour, P., \& Fallah, E. (2015). An investigation into the impact of reflective teaching on EFL learners' autonomy and intrinsic motivation. Cypriot Journal of Educational Science, 10(4), 305-315.

Abednia, A., Hovassapian, A., Teimournezhad, S., \& Ghanbari, N. (2013). Reflective journal writing: Exploring in-service EFL teachers' perceptions. System, 41, 503-514.

Akbari, R. (2007). Reflections on reflection: A critical appraisal of reflective practices in L2 teacher education. System, 35(2), 192-207.

Akbari, R., Behzadpoor, F., \& Dadvand, B. (2010). Development of English language teaching reflection inventory. System, 38(2), 211-227.

Al Harthy, S. S. H., Jamaluddin, S., \& Abedalaziz, N. D. (2013). Teachers' attitudes and performance: An analysis of effects due to teaching experience. International Interdisciplinary Journal of Education, 2(9), 888893.

Ashrafi, N., Talebinejad, M. R., \& Shahrokhi, M. (2020). The contribution of core reflection supervision through the onion model to Iranian EFL teachers' professional development. Teaching English Language, 14(2), 89110.

Attema-Noordewier, S., Korthagen, F. A. J., \& Zwart, R. C. (2013). Core reflection in primary schools: A new approach to educational innovation. In: F. A. J. Korthagen, Y. M. Kim, \& W. L. Greene (Eds.), Teaching and learning from within: A core reflection approach to quality and inspiration in education (pp. 111-130). New York: Routledge.

Beauchamp, C. (2015). Reflection in teacher education: issues emerging from a review of current literature. Reflective Practice, 16, 123-141.

Bell, A., Kelton, J., McDonagh, N., Mladenovic, R., \& Morrison, K. (2011). A critical evaluation of the usefulness of a coding scheme to categorise levels of reflective thinking. Assessment and Higher Education, 36(7), 797-815.

Bentea, C.-C., \& Anghelache, V. (2012). Teachers' motivation and satisfaction for professional activity. Procedia - Social and Behavioral Sciences, 33, 563-567

Black, G.L. (2015). Developing teacher candidates' self-efficacy through reflection and supervising teacher support. In Education, 21(1), 78-98.

Boody, R. M. (2008). Teacher Reflection as Teacher Change, and teacher change as moral response. Education, 128(3), 498-506.

Braun, J.A., \& Crumpler, T. P. (2004). The social memoir: An analysis of developing reflective ability in a pre-service methods course. Teaching and Teacher Education, 20, 59-75. 


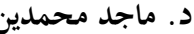

Buehl, M. M., \& Fives, H. (2009). Exploring teachers' beliefs about teaching knowledge: Where does it come from? Does it change? The Journal of Experimental Education, 77(4), 367-407.

Buitink, J. (2009). What and how do student-educators learn during schoolbased teacher education. Teaching and Teacher Education, 25, 118-127.

Burbank, M., Ramirez, L., \& Bates, A. (2012). Critically reflective thinking in urban teacher education: A comparative case study of two participants' experiences as content area teachers. The Professional Educator, 36(2), 1-17. Campoy, R. (2010). Reflective thinking and educational solutions: Clarifying what teacher educators are attempting to accomplish. SRATE Journal, 19(2), 15-22.

Cavilla, D. (2017). The Effects of Student reflection on academic performance and motivation. Sage Open, 7(3), 1-13.

Cirocki, A. , \& Widodo, H. P. (2019). Reflective practice in English language teaching in Indonesia: Shared practices from two teacher educators. Iranian Journal of Language Teaching Research, 7(3), 15-35.

Chang, B. (2019). Reflection in learning. Online Learning, 23(1), 95-110.

Choy, S. \& Oo, P. (2012). Reflective thinking and teaching practices: A precursor for incorporating critical thinking into the classroom. International Journal of Instruction, 5(1), 167-182.

Cohen, L., Manion, L., \& Morrison, K. (2000). Research methods in education. London, UK: Routledge-Falmer.

Collin, S., \&Karsenti, T. (2012).The role of online interaction as support for reflective practice in pre-service teachers.Teaching \& Teachers, 20 (2).

Conway, P. F., Clark, C. M. (2003). The journey inward and outward. A reexamination of Fuller's concern-based model of teacher development. Teaching and Teacher Education, 19(5), 465-482.

Cox, E. (2005). Adult learners learning from experience: Using a reflective practice model to support work-based learning. Reflective Practice, 6(4),459-472.

Cristina-Corina, B., \& Valerica, A. (2012). Teachers' perceptions and attitudes towards professional activity. Procedia-Social and Behavioral Sciences, 51, 167-171.

Cunningham, F. M. (2001). Reflecting teaching practice in adult ESL settings. ERIC Digest, 1-7.

Daudelin, M. W. (1997) Learning from experience through reflection, Organizational Dynamics, 24(3), 36-48.

Dewey, J. (1933). How we think: A restatement of the relation of reflective thinking to the educational process. Lexington, MA: D. C. Heath.

Dymoke, S. \& Harrison, J. (2008). Reflective teaching and learning. Sage: London \& Thousand Oaks CA. 


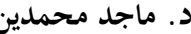

Erginel-ġanal, S. (2006). Developing reflective teachers: a study on perception and improvement of reflection in pre-service teacher education (Doctoral dissertation). Middle East Technical University, Turkey.

Farrell, T. S. C. (2004). Reflective practice in action: 80 reflection breaks for busy teachers. Thousand Oaks, California: Corwin Press, Sage Publication Company.

Farrell, T. S. C. (2007). Reflective language teaching: From research to practice. London: Continuum International Publishing Group.

Farrell, T. S. C. (2011). 'Keeping SCORE': Reflective practice through classroom observations. RELC Journal, 42(3). 265-272.

Fatemipour, H., \& Hosseingholikhani, F. (2014). The impact of reflective teaching on the EFL teachers' performance. Journal of Educational and Management Studies, 4(4), 796-799.

Fendler, L. (2003). Teacher reflection in a hall of mirrors: Historical influences and political reverberations. Educational Researcher, 32(3), 1625.

Finkel, L., and Fletcher, S. (2002). The Portfolio/Colloquium to Certify Competence and Assess Program Goals: Balancing Program Requirements and Assessment with Candidates' Experiences. The annual meeting of the American Educational Research Association, New Orleans, April, 2002.

Genc, Z. S. (2010). Teacher autonomy through reflective journals among teachers of English as a

foreign language in Turkey. Teacher Development, 14, 397-409.

Good, J.M., \& Whang, P.A. (2002). Encouraging reflection in preservice teachers through response journals. The Teacher Educator, 37, 254-267.

Güngör, M. N. (2017). Turkish Pre-Service teachers' reflective practices in teaching English to young learners. Australian Journal of Teacher Education 41(2), p.137-51.

Halter, C. P. (2006). The reflective lens: The effects of video analysis on preservice teacher development (Doctoral dissertation). University of California, San Diego.

Harland, D. J., \& Wondra, J. D. (2011). Preservice teachers' reflection on clinical experiences: A comparison of blog and final paper assignments. Journal of Digital Learning in Teacher Education, 27(4), 128-133

Hettiarachchi, S. (2013). English language teacher motivation in Sri Lankan public schools. Journal of Language Teaching and Research, 4(1), 1-11.

Hürsen, Ç. (2012). Determine the attitudes of teachers towards professional development activities. Procedia Technology, 1, 420-425

Hsieh, B. (2015). The importance of orientation: implications of professional identity on classroom practice and for professional learning. Teachers and Teaching: Theory and Practice, 21, 178-190. 
د. ماجد محمدين

Hubbs, D., \& Brand, C. F. (2010). Learning from the inside out: A method for analyzing reflective journals in the college classroom. Journals of Experiential Education, 33(1), 56-71.

Hussein, H. (2018). Examining the effects of reflective journals on students' growth mindset. IAFOR Journal of Education, 6(2). 33-50.

Impedovo, M. A., \& Malik, S. K. (2016). Becoming a reflective in-service teacher: Role of research attitude. Australian Journal of Teacher Education, $41(1), 6$.

Islam, S. \& Shuchi, I. J. (2017). Deconstruction of method-postmethod dialectics in English language teaching. Journal of Language Teaching and Research, 8(3), 539-547.

Javadi, F., \& Khatib, M. (2014). On the relationship between reflective teaching and teachers' burnout. International Journal of Research Studies in Language Learning, 3(4), 85-96.

Johnson, K. E. (2009). Second language teacher education: A sociocultural perspective. London: Routledge.

Jones, M., \& Ryan, J. (2014). Learning in the practicum: Engaging preservice teachers in reflective practice in the online space. Asia-Pacific Journal of Teacher Education, 42(2), 132-146.

Jung, J. (2012). The focus, role, and meaning of experienced teachers' reflection in physical education. Physical Education and Sport Pedagogy, 17, 157-175.

Kalk, K., Luik, P., Taimalu, M., \& Taht, K. (2014). Validity and reliability of two instruments to measure reflection: A confirmatory study. Trames,18(68/63), 2, 121-134.

Killeavy, M., \& Moloney, A. (2010). Reflection in a social space: Can blogging support reflective practice for beginning teachers? Teaching and Teacher Education,26(4), 1070-1076.

Kizilcik, H., \& Daloglu, A. (2018). Implementing an interactive reflection model in EAP. Australian Journal of Teacher Education, 43(9), 1-27.

Klein, S. (2008). Holistic reflection in teacher education: Issues and strategies. Reflective Practice, 9, 111-121.

Körkkö, M., Kyrö-Ämmälä, O. \& Turunen, T. (2016). Professional development through reflection in teacher education. Teaching and Teacher Education, 55, 198-206.

Korthagen, F. A. J. (2004). In search of the essence of a good teacher: towards a more holistic approach in teacher education. Teaching and Teacher Education, 20, 77-97.

Korthagen, F. A. J. (2014). Promoting core reflection in teacher education: Deepening professional growth. In L. Orland-Barak \& C. J. Craig (Eds), International teacher education: Promising pedagogies (pp. 73-89). Bingley, U.K.: Emerald. 


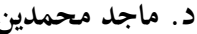

Korthagen, F. A. J. (2016). Pedagogy of teacher education. In J. Loughran \& M.L. Hamilton, International handbook of teacher education, (pp. 311-346). Singapore: Springer Science.

Korthagen, F. A. J. (2017). Inconvenient truths about teacher learning: Towards professional development 3.0. Teachers \& Teaching: Theory and Practice, 23(4), 387-405.

Korthagen, F. A. J., \& Nuijten, E.E. (2017). Core reflection approach in teacher education. In: J. Lampert (Ed.), Oxford research encyclopedia of education (pp. 189-206). New York: Oxford University Press.

Korthagen, F., \& Vasalos, A. (2005). Levels in reflection: Core reflection as a means to enhance professional development. Teachers and Teaching: Theory and Practice, 11(1), 47-71.

Korthagen, F. A. J., \& Vasalos A. (2010). Going to the core: Deepening reflection by connecting the person to the profession. Handbook of reflection and reflective inquiry (pp. 529-552). Boston, MA: Springer.

Lee, H. J. (2005). Understanding and assessing pre-service teachers' reflective thinking. Teaching and Teacher Education, 21, pp. 699-715.

Liu, L., \& Zhang, L. (2014). Enhancing teachers' professional development through reflective teaching. Theory and Practice in Language Studies, 4(11), 2396-2401.

Lord, G., \& Lomicka, L. (2007). Foreign Language Teacher Preparation and Asynchronous CMC: Promoting reflective teaching. Journal of Technology and Teacher Education, 15(4), 513-532.

Loyghran, J. J. (2002). Effective reflective practice: In search of meaning in learning about Teaching. Journal of Teacher Education, Vol. 53(1), 33-43.

Malmir, A. (2018). Teachers' Reflective Teaching and Self-Efficacy as Predicators of their Professional Success. Research in English Language Pedagogy, 6(1): 117-138

Mansvelder-Longayroux, D. D., Beijaard, D., \& Verloop, N. (2007). The portfolio as a tool for

stimulating reflection by student teachers. Teaching and Teacher Education, 23, 47-62.

Meijer, P. C., Korthagen, F. A. J., \& Vasalos, A. (2009). Supporting presence in teacher education: The connection between the personal and professional aspects of teaching. Teaching and Teacher Education, 25(2), 297-308.

Minott, M. A. (2006). Reflection and reflective teaching: A case study of four seasoned teachers in the Cayman Islands. (Ph.D. Dissertation), University of Nottingham, Nottingham, England.

Muir, T., \& Beswick, K. (2007). Stimulating Reflection on Practice: Using the Supportive Classroom Reflection Process, Mathematics Teacher Education and Development, 8, 74-93. 
Korthagen's Onion Model and its Effectiveness in Developing Reflective Thinking Skills and Attitudes Toward the Profession among EFL Student-Educators

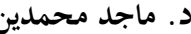

Nur, F. \& Cephe, P. (2017). Actualization of the onion model of reflection in Turkish English Language instructors' practices. Educational Research and Reviews, 12(2), 62-72.

Pacheco, A. Q. (2005). Reflective teaching and its impact on foreign language teaching. Numero Extraordinario, 5, 1-19.

Pagano, M., \& Roselle, L. (2009). Beyond reflection through an academic lens: Refraction and international experiential Education. Frontiers, 18, 217-229.

Perry, B. \& Stewart, T. (2005). Insights into effective partnership in interdisciplinary team teaching. System, 33, 563-573

Pedro, J., Abodeeb-Gentile, T. \& Courtney, A. (2012). Reflecting on literacy practices: Using reflective strategies in online discussion and written reflective summaries. Journal of Digital Learning in Teacher Education. 29(2), 39-47.

Pollard, A., Anderson, J., Maddock, M., Swaffield, S., Warin, J., and Warwick, P. (2008). Reflective teaching (3rd. ed.). London: Continuum.

Procee, H. (2006). Reflection in education: A Kantian epistemology. Educational Theory, 56(3), 237-253.

Putney, L. G., \& Broughton, S. (2010). Developing teacher efficacy through reflection: A Vygotskian perspective. Critical Issues in Teacher Education, 16, 4-17.

Rodgers, C. (2002). Defining reflection: Another look at John Dewey and reflective thinking. Teachers College Record, 104(4), 842-866.

Romano, M., \& Schwartz, J. (2005). Exploring technology as a tool for eliciting and encouraging beginning teacher reflection. Contemporary Issues in Technology and Teacher Education, 5(2), 149-168.

Rudd, R. D. (2007). Defining Critical Thinking. Techniques, 82(7), 46-49.

Salehi, H., Taghavil, E., \& Yunus, M. (2015). Relationship between teachers' job satisfaction and their attitudes towards students' beliefs and motivation. English Language Teaching, 8(7), 46-61.

Sezer, R. (2008). Integration of Critical Thinking Skills into Elementary School Teacher Education Courses in Mathematics. Education, 128(3), 349362.

Sireesha, A., \& Reddy, M. S. (2015). A study of attitude of Telugu language teachers towards teaching profession with management and qualification. International Journal of Scientific Research, 4(5), 2277-8179.

Smadi, O. M., \& Al-Ghazo, A. (2013). Jordanian teachers' attitudes toward foreign language teaching and their relationship to these teachers' classroom practices. Journal of Education and Practice, 4(17), 62-86.

Smerci, C. (2007). Developing a reflective thinking tendency scale for teachers and student teachers. Educational Sciences: Theory and Practice, 7(3), 1369-1376. 
د. داجد محمدين

Sööt, A., \& Viskus, E. (2015). Reflection on teaching: A way to learn from practice. Procedia-Social and Behavioral Sciences, 191, 1941-1946. Stiller, G. M., \& Philleo, T. (2003). Blogging and blogspots: An alternative format for encouraging reflective practice among preservice teachers. Education,123(4), 789.

Sun, Y. (2010). Developing reflective cyber communities in the blogosphere: A case study in Taiwan higher education. Teaching in Higher Education, 15(4), 369-391

Taggart, G. L., \& Wilson, A. P. (2005). Promoting reflective thinking in teachers: 50 action strategies (2nd ed.). Corwin Press: England

Tarman, B. (2012). Prospective Teachers' Beliefs and Perceptions about Teaching as a Profession. Educational Sciences: Theory and Practice, 12(3), 1964-1973.

Tan, K. S. (2002). Reflective learning in the classroom. REACT, 2, 101-109.

Tillema H.H. (2006). Constructing knowledge in professional conversations. The role of beliefs on knowledge and knowing. Learning and Instruction, 16(6), 592-608.

Trivedi, R. P. (2012). A study of teachers' attitude of teachers towards teaching profession teaching at different level. International Multidisciplinary e-Journal, 24-30.

Uzum, B., Petrón, M., \& Berg, H. (2014). Pre-service teachers ${ }^{\text {ee first foray }}$ into the ESL Classroom: Reflective practice in a service-learning project. TESL-EJ, 18(3).

Vermunt, J. D., \& Endedijk, M. D. (2010). Patterns in teacher learning in different phases of the professional career. Learning and Individual Differences, 21, 294-302.

Welsh, R., \& Delvin, P. (2006). Developing pre-service teachers ${ }^{\text {ee }}$ reflection: Examining the use of video. Action in Teacher Education, 28(4), 53-61.

Yang, S. H. (2009). Using blogs to enhance critical reflection and community of practice. Educational Technology \& Society, 12, 11-21.

Zanting, A., Verloop, N., \& Vermunt, J. D. (2003). How do Studenteducators Elicit their Mentor Teachers' Practical Knowledge?. Teachers and Teaching: theory and practice, 9, 197-211.

Zeichner, K. M., \& Liston, D. P. (2013). Reflective teaching: An introduction. USA: Lawrence Erlbaun Associates Inc.

Zulfikar, T., \& Mujiburrahman (2018). Understanding own teaching: Becoming reflective teachers through reflective journals. Reflective Practice 19(1), 1-13.

Zwart, R. C., Korthagen, F. A., \& Attema-Noordewier, S. (2015). A strength-based approach to teacher professional development. Professional Development in Education, 41(3), 579-596. 